Pablo Mejía Reyes*

Marlen Rocio Reyes Hernández"

Paolo Riguzzi*"
Recibido: 2 de diciembre de 2019

Concepto de evaluación: 1 de marzo de 2020

Aprobado: 13 de mayo de 2020

Artículo de investigación

(C) 2020 Universidad Católica de Colombia.

Facultad de Ciencias

Económicas y Administrativas.

Todos los derechos reservados

* Ph.D. in Economics, University of Manchester. Professor-researcher at the Center for Research in Economic Sciences,

Faculty of Economics, Universidad Autónoma del Estado de México, México

D.F.Email: pmejiare@uaemex.mx

(D) https://orcid.org/0000-0002-9222-1526.

Mailing address: Cerro de Coatepec $S / N$, Ciudad Universitaria Toluca, Edo. de México C.P. 50110.

** Ph.D. in Administrative Economic Sciences, Universidad Autónoma del Estado de México. Professor-researcher at the Center for Research in Economic Sciences, Faculty of Economics, Universidad Autónoma del Estado de México, México

D.F. Email: mrreyesh@uaemex.mx

(D https://orcid.org/0000-0002-8339-4011.

*** Ph.D. in History, University of Genoa. Professor-researcher at El Colegio de México, México D.F. Email: priguzzi@colmex.mx

(D) https://orcid.org/0000-0002-2342-7467.
Revista Finanzas y Política Económica, Vol. 12, N. ${ }^{\circ} 1$, enero-junio, 2020, pp. 235-269 https://doi.org/10.14718/revfinanzpolitecon.v12.n1.2020.3061

\section{Political budget cycles in Latin America, 1982-20141}

\begin{abstract}
This paper aims to detect the presence of political budget cycles (PBuCs) around presidential elections in four large Latin American countries (Argentina, Chile, Colombia, and Mexico) over the 1982-2014 period, in the framework of democratic regimes. Extended autoregressive models are estimated for total public expenditure and their chief components, considering the effect of economic fluctuations. Among the most important findings, weak evidence of $\mathrm{PBuCs}$ was found in the case of Argentina and Chile, while in the case of Mexico and Colombia, post-electoral adjustments in budget items sensitive to political manipulation were found, such as subsidies and public works, along with pre-electoral increases in total expenditure in the former one, and in goods and services in the latter.
\end{abstract}

Keywords: political budget cycle, public expenditure, Latin America.

JEL Classification: E32, E62, H12, H30

1 The authors acknowledge comments received from the reviewers, as well as research assistance from Gina Sánchez-Peña and Karen T. SánchezCastañeda. Remaining errors and omissions, as usual, are the authors' responsibility. 


\section{Ciclos políticos presupuestales en América Latina, 1982-2014}

\section{Resumen}

El objetivo de este artículo es detectar la presencia de ciclos políticos presupuestales (CPP) en torno a las elecciones presidenciales de cuatro grandes países latinoamericanos (Argentina, Chile, Colombia y México) durante el periodo 1982-2014, en el contexto de regímenes democráticos. Para ello, se estiman modelos autorregresivos extendidos para gasto público total y sus componentes principales, considerando el efecto de las fluctuaciones cíclicas. Entre los hallazgos más importantes está la evidencia débil de CPP en los casos de Argentina y Chile, mientras que en los casos de México y Colombia se encontraron ajustes postelectorales en partidas presupuestarias sensibles a la manipulación política, como subsidios y obras públicas, junto con aumentos preelectorales en el gasto total en el primero, y en bienes y servicios en el segundo.

Palabras clave: ciclo político presupuestal, gasto público, América Latina. 


\section{INTRODUCTION}

Economists have long been interested in determining the causes, transmission mechanisms, and consequences of the cyclical fluctuations of economic activity. Despite the persistence of conflicting interpretations, it is widely accepted that the causes of these cycles are related to supply shocks (mainly technological innovations), demand shocks (economic policy adjustments), and changes in the economic agents' perceptions (Sherman, 1991; Romer, 2006). Nevertheless, the historical evidence shows that political factors have also played a relevant role in generating economic fluctuations. In his seminal paper, Nordhaus (1975) addressed the influence of elections on the making of economic policy and their effects on variables that might gain electoral votes. Essentially, he assumed that citizens are shortsighted and interested only in the recent performance of macroeconomic variables that might directly affect them. Because of this, governments (and their political parties) could follow expansive policies before elections to spur production and employment, and, hence, to convince voters that they are competent managers of the economy. Moreover, voters generally do not realize that these policies tend to generate imbalances that need to be corrected after the elections by the incoming government, which would be obliged to adopt restrictive measures that could reduce economic activity in the future. Because of their origin, these cyclical patterns have been named political business cycles (PBC) (Dubois, 2016).

The international empirical evidence on the existence of political cycles, however, is ambiguous (McCallum, 1978; Alesina, 1989, among others). Considering the above, Weatherford (1987) argued that even if PBC models offer a sensible explanation of the motivations of governments to manipulate the economy for the purpose of gaining votes, these outcomes (real effects) rarely occur. Therefore, following the publication of Tufte's (1978) paper on the experience of the United States and other high-income democracies, the analytical focus moved to the manipulation of fiscal instruments for electoral purposes. In other words, the attention shifted from the study of the "ends" towards the investigation of the dynamics of the "means." Because of its nature, this phenomenon has been called a political budget cycle (PBuC), defined by Shi and Svensson (2003: 67) as "a periodic fluctuation in a government's fiscal policies, which is induced by the cyclicality of elections."

The PBuC research agenda felt the impact of the rational expectations theory, starting with the famous work by Lucas (1972), which, rejecting axiomatically that manipulation of fiscal variables for political purposes were an option, inhibited the development of research in this area. Thus, optimizing individuals, who have 
complete information and are capable of fully discerning the future, could not be repeatedly deceived, nor would politicians, as rational actors, devote energy to carry out such an inefficient scheme. As succinctly stated by Persson and Tabellini (2000), it would be highly problematic to combine the fully rational actuation of individuals as economic agents with their manipulation as voters. Within this theoretical framework, the existence of PBuCs could hardly have scientific standing.

Later, a helpful revision of the scope of the rational expectations assumption spurred by economic psychology and its analysis of cognitive mechanisms has explained how the formation and maintenance of wrong beliefs and perceptions on reality might be constitutive of individuals' mental maps in every society (Kahneman, 2003; North, 2005). This, in turn, indirectly contributed to fostering the resumption of research on PBuCs with greater conceptual sophistication and more refined instruments to measure them.

At the same time, the research on PBuCs, previously restricted to the OECD area, was extended to middle- and low-income countries that are characterized by having younger democratic regimes and higher levels of institutional fragility. Particularly, a number of studies have investigated this phenomenon in several Latin American countries. This literature can be classified in three groups according to the methodology used.

First, by applying extended autoregressive (AR) models, Remmer (1993) analyzed fourteen elections in eight Latin American countries, finding no evidence of PBuCs in their fiscal balances. Later, Ogura (2000) detected an increase in the wage bill paid by Brazilian incoming governments during their first year in office, owing to the lag in the impact of wages raised before elections, for political aims.

In a second group that analyzes the experience of Mexico with AR models, Magaloni (2000) reports evidence of PBuCs in total public expenditure, but also finds that the estimates of post-electoral contractions lose statistical significance when the unemployment rate is included as a control variable, which may imply that the decline is, in fact, caused by recessions that often occurred during the first year of several administrations. ${ }^{1}$ In addition, González (2002) concludes that the magnitude of the cycles increases along with a country's democratization process, since political competition brings about a greater chance of losing elections, which leads governments to overspend in order to gain votes. On the other hand, Reyes

1 In Mexico, fiscal adjustments have been carried out during the first year of various administrations to deal with recessions provoked by macroeconomic imbalances (1983 and 1995) or international crises (2001). 
and Mejía (2016) estimate extended autoregressive and moving average models that include the effects of economic factors (captured by fluctuations in manufacturing production) and find evidence of PBuCs in total expenditure as well as in current and capital expenditures.

Finally, the third group of studies based on panel data models deals with larger country samples, including Latin America, and incorporates more variables, such as fiscal balance, total expenditure and revenues, primary expenditure, transferences and subsidies, as well as current and capital expenditures. Their findings indicate that voters are more susceptible to manipulation through current expenditures (Nieto-Parra \& Santiso, 2012; Kraemer, 1997), and that the presence of PBuCs is conditional on a country's degree of democratic consolidation (Barberia \& Avelino, 2011; Klomp \& De Hann, 2013; Brender \& Drazen, 2005).

\section{OBJECTIVES}

Although these studies have shed light on the elusive phenomenon of PBuCs in several Latin American countries, the evidence is still rather mixed. In this paper, we revisit this topic and evaluate the $\mathrm{PBuC}$ hypothesis in four of the most important economies in Latin America: Argentina, Colombia, Chile, and Mexico. ${ }^{2}$ In particular, we seek to determine whether or not different components of the public expenditure actually do increase significantly prior to presidential elections in order to bias voters' preferences towards incumbent parties, even though those expenses would have to be cut back after the elections to correct the resulting imbalances.

These four countries share common institutional features, such as a presidential system with bicameral congresses and a large number of political parties. They differ, nonetheless, in their political organization, since Argentina and Mexico have federal systems, while Colombia and Chile are unitary republics. The period under consideration (1982-2014) was characterized by a political transition from authoritarian regimes, including military dictatorship in two out of the four countries, to democratic systems that have gradually been consolidated. ${ }^{3}$ Allowing for Colombia's longer democratic trajectory, despite a prolonged civil war, the development of

2 Brazil has not been included in the analysis due to the unavailability of disaggregated data on public expenditure for some years.

3 It is usually accepted that until 1978 only Costa Rica, the Dominican Republic, Venezuela, and Colombia (weakly) could be classified as developed democracies in Latin America (Payne et al., 2006). 
Pablo Mejía Reyes • Marlen Rocio Reyes Hernández • Paolo Riguzzi

democracy and electoral competition was the paramount feature in the selected countries (Taylor, 2009).

Notwithstanding the existence of an ongoing discussion regarding the quality of Latin American democracies (Mainwaring \& Pérez Liñán, 2006; Smith, 2012), democratic rules seem to have consistently structured the path to accessing power in the area, fulfilling the general requisite for PBuCs: the existence of competitive elections. ${ }^{4}$

Our analysis covers twenty-four presidential elections carried out under democratic regimes in the above-mentioned countries, according to the following distribution: seven elections in Argentina, since 1983; eight in Colombia, since 1986; six in Chile, since 1989, and three in Mexico, since 2000.

This paper aims to contribute to the literature on PBuCs by introducing two variants into the analysis. First, single-equation models are estimated for each country to obtain specific evidence for each case and, in that sense, supplement the findings reported in studies that use panel data methods, which actually estimate the average effect of elections on the complete set of fiscal indicators in the sample. Second, the introduction of control variables in the model allows us to avoid the identification of spurious PBuCs that may result from the use of fiscal policies to stabilize business cycles.

\section{THEORETICAL CONSIDERATIONS}

Like general macroeconomics, $\mathrm{PBC}$ and $\mathrm{PBuC}$ models have substantially changed over time in function of the role assigned to agent expectations. The first generation of PBC models was based on three key assumptions. First, the economy was characterized by a Phillips curve "augmented" with inflation expectations, where voters valued high employment rates positively, and high unemployment rates, negatively. Second, inflation expectations are adaptive in the sense that they are formed based on history in the same variable. Third, voters are shortsighted, with short-run memory, which drives them to cast their vote in response to the recently observed performance of their economies (mainly production and employment). The combination of these conditions encouraged politicians to engage in opportunistic behaviors, resulting in implementing expansive policies before elections,

$4 \quad$ Brender and Drazen (2005) stress that, both from empirical and conceptual standpoints, democratic elections are an indispensable requirement for the occurrence of a PBuC. 
followed by restrictive adjustments later, to correct the resulting macroeconomic imbalances (Nordhaus, 1975). ${ }^{5}$ Consequently, within this frame, public finances tended to display cyclical patterns linked to the elections.

A new generation of PBC models, which allow for opportunistic or partisan motivations, have incorporated rational expectations (Borsani, 2003). Under these assumptions, agents form their expectations based on all available information: they have full knowledge of the evolution of and interactions between the variables of interest, as well as of their governments' reaction functions. Thus, they cannot be systematically deceived. Hence, opportunistic behavior is constrained since politicians, anticipating a null response from voters to manipulation, have scarce incentives to activate PBuCs.

Nonetheless, under conditions of asymmetric information and bounded rationality, it is possible for $\mathrm{PBuC}$ to emerge from the opportunistic behavior of incumbents. Because of this, some recent studies have made room for two plausible assumptions that have not been refuted by empirical research. First, there seems to be political benefits for parties in power when their voters perceive that the economy is performing well (Hibbs, 2006); the size of such benefits varies and is contingent on each country's institutional framework, which defines the incentives for engaging in fiscal manipulation before elections. Second, the voters' bounded rationality and short memory can lead them to overestimate the economy's immediate past performance as an indicator of its general condition (Olters, 2012). ${ }^{6}$

Moreover, there may be informational asymmetries in the decision-making processes typical of principal-agent relationships, combined with elements of moral hazard: politicians know better than their citizens their actual ability to manage the economy (Aboal, Lorenzo \& Oddone, 2001). Governments engage in a signaling game to impress the voters with their efficiency in implementing stabilization policies, although they may not be always successful in this (Rogoff, 1990). Thus, it will not always be optimal for governments to try to artificially improve their reputation.

5 In an alternative partisan view, Hibbs (1977) posits that political parties behave according to ideological motivations and maximize their objective function that weights differently the cost of unemployment in relation to inflation. In that sense, parties are located at different points on an augmented Phillips curve throughout their periods in office. Right-wing parties privilege the control of inflation over employment, while left-wing ones adopt the opposite priority. See Alesina (1987) and Alesina and Sachs (1988) for further insights on partisan models.

6 The fact that a backward-looking perspective shapes the electoral choice of a proportion of citizens does not exclude the existence of forward-looking individuals, who behave according to the rational expectations assumption. 
Pablo Mejía Reyes • Marlen Rocio Reyes Hernández • Paolo Riguzzi

Hence, in these models the manipulation of fiscal variables is expected to be less systematic and evident than in the Nordhaus model, and the predicted cycles are shorter and less regular. ${ }^{7}$

It is important to stress that the size of information asymmetries and, therefore, the politicians' opportunity to manipulate economic policy vary according to their institutional settings. It could be claimed, in a stylized form, that "open access societies" - characterized by high per capita income, robust democracies, rule of the law, accountability, high levels of human capital, and the existence of numerous civic organizations-provide information relevant for the public opinion, which can effectively restrict the incentives for the incumbent governments to engage in political opportunism (North, Wallis \& Weingast 2009; Brender \& Drazen, 2003). Conversely, "limited access societies" - where the mentioned elements only exist in a fragmentary and reduced form and usually entail high information costs-offer greater opportunities for political manipulation, as well as for impunity for engaging in such behavior (Shi \& Svensson, 2000, 2006). Therefore, opportunistic government behavior tends to appear more in emerging economies due to their institutional fragilities, which allow greater discretionary power in the management of fiscal variables (Schuknecht, 1996). Because of this, a contextual determination of PBuCs is necessary according to the specific properties of the political institutions in each country (Franzese \& Jusko, 2008).

This view differs from the democratic learning model formulated by Brender and Drazen (2005), which assumes that "new democracies" differ from "consolidated democracies" regarding the actual possibilities for the emergence of PBuCs. In their model, countries that transit to or return to democracy undergo the effect of democratic inexperience on PBuCs until most of the citizens have learned the political game. For practical purposes, these authors claim that the "new democracy" status extends through four successive elections after the initial implementation of democratic rules, after which it is assumed that voters would have completely learned how the system works and these procedures would have become fully institutionalized.

However, no definitive theoretical reasons exist for assuming that democratic transitions evolve only in an incremental and linear way. In fact, empirical evidence points at regressions and stagnations occurring in these processes. Therefore, the consolidation of democracies rather depends on the institutional configuration of

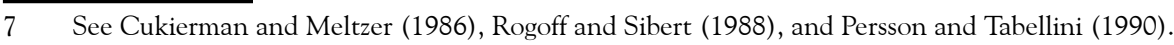


specific societies, and the structure of the relations between their economies and politics.

At the same time, since institutional features that shape the relationship between the executive and the legislative branches play a relevant role in the emergence of PBuCs, it is important to identify the features of the budget process in each country (Saporiti \& Streb, 2008). Despite the existence of a variety of institutional arrangements in the countries analyzed, the executive branch in each one is responsible for proposing an annual budget plan to the Congress, usually with some restrictions on the increase in fiscal deficit or in public expenditure. Congresses have a deadline to promulgate their budgets, and in some countries, the executive holds veto power, either globally or by item, on modifications to the budget, although legislators can overcome vetoes by a qualified majority.

A crucial issue for which systematized information is still scarce is the effective degree of control that governments have over the execution of budgets, particularly, regarding their ability to reassign funds between items during the fiscal year. Despite formal mechanisms for auditing and overseeing public accounts, the available evidence points to a limited capacity of control on the part of legislators, which makes possible fiscal manipulation for electoral aims (Santiso, 2007).

\section{ECONOMETRIC METHODOLOGY}

In this paper, we estimate extended autoregressive models for different components of the public expenditure to identify PBuC patterns in Argentina, Chile, Colombia, and Mexico. ${ }^{8}$ Following a generalized practice in the literature, dichotomous variables are added to capture any difference that occurs in the growth rates of these variables during the election year and the prior one, versus the growth rates of the subsequent year. In other words, if incumbents do manipulate public spending for electoral purposes, growth rates would be above the mean in the former case, and below (even with negative values) in the year following elections. It should be noted that the alternation of the signs of the manipulation of public expenditure around elections has a short-lived impact. Hence, the dummy variables seek to measure the immediate effects of the presence or absence of elections.

8 This approach allows identifying country-specific characteristics, which is not possible in the joint analysis of large samples. 
In order to avoid biases due to specification errors that result from omitted variables, two control variables are introduced. First, an output measure is used to isolate the effects of business cycles on government expenditures (Grier, 1987; Pepinsky, 2007), since fiscal cuts may be aimed at containing recessions rather than being an adjustment to electoral overspending. In this case, the dynamics of expenditure would respond to macroeconomic stabilization objectives. Given that fiscal policies implemented in Latin America have been mainly pro-cyclical, it would be easy to misinterpret restrictive stabilization policies for post-electoral adjustments. ${ }^{9}$ Second, total public revenue, i.e. tax revenues plus new public debt, is also introduced as a control variable with the purpose of measuring a government's spending capacity during the current year, because the size of its spending constrains the electoral manipulation of expenditures. Based on these considerations, the general model to be estimated is specified as follows:

$$
g_{k t}=\alpha_{0}+\sum_{i=1}^{p} \alpha_{i} g_{k t-i}+\gamma c_{t}+\delta i_{t}+\beta_{a} e_{\tau-1}+\beta_{e} e_{\tau}+\beta_{d} e_{\tau+1}+\varepsilon_{t}
$$

where $g_{k t}$ denotes the annual growth rate of the $k$-th component of public expenditure; $c_{t}$ is an indicator of the business cycle measured by GDP growth rates or GDP deviations from the underlying trend estimated by means of the Hodrick and Prescott filter (1997). ${ }^{10} i_{t}$ denotes the growth rate of total public revenues, and $\varepsilon_{t}$ is a perturbation that follows a Gaussian white noise process such as $\varepsilon_{\mathrm{t}} \sim \operatorname{iidN}\left(0, \sigma^{2}\right)$ that meets the assumptions of a linear regression. In turn, $e_{\tau}$ is the dummy variable that accounts for the effects of elections on public expenditure, and then $e_{\tau}=1$ when the $\tau$-th election is celebrated, and 0 , otherwise. The variables $e_{\tau-1}$ and $e_{\tau+1}$ are defined in an analogous manner to account for the effects of elections over the years previous and subsequent to elections, respectively. ${ }^{11}$

$9 \quad$ Fiscal policy in Latin America has been essentially pro-cyclical, with increases in public expenditure occurring during expansions, and adjustments during recessions, not only due to the contraction of revenues, but also due to the notion that macroeconomic balances, especially the fiscal ones, must be strengthened during recessive phases, to lessen instability and to attract investment, allowing economic recovery to occur (Gavin \& Perotti, 1997; Talvi \& Végh 2005).

10 Growth rates can be considered as an approximation of the classical business cycle (Osborn, Pérez \& Sensier, 2005), which is defined as the alternation of phases of expansion and recession. In turn, deviations of production from their underlying trends are associated with the concept of growth cycles (Lucas, 1977).

11 Notice that working with annual data only allows this specification, since it is not possible to capture the effects of elections celebrated in the mid-year over the previous and subsequent twelve months (or four quarters), an issue known as time aggregation (Streb, Lema \& Garofalo, 2012). For an analysis based on quarterly data, which allows distinguishing different time effects, see Reyes and Mejía (2016). 
The coefficients of the model are expected to have appropriate statistical properties and values consistent with theory. In particular, the values of the autoregressive coefficients $\alpha_{i}$, which measure the persistence of the series, should guarantee that public expenditure is a stationary process; their order is determined by minimizing the Akaike information criterion..$^{12}$ In turn, if the dynamics of public expenditure are driven by opportunistic behavior, it is expected that $\beta_{a^{\prime}} \beta_{e}>0$ and $\beta_{d}<0$. On the other hand, $\gamma<0$ if fiscal policy responds to stabilizing criteria, and vice versa. Finally, if expenditures are conditioned by the revenues, $\delta>0$. To avoid collinearity between the cycle indicator and total revenues (due to their high correlation), models are estimated incorporating only one of these two variables.

The series of total public expenditure as well as its components (current and investment expenditure) are analyzed for the four countries studied within this framework. This disaggregation allows us to distinguish electoral manipulation in different spending items. Particularly, it is expected that consumption transfers (current expenditure) have a more direct effect than spending on public works (investment expenditures), since the former presents the voters with immediate benefits, although both outlays may work in the same direction.

\section{EVIDENCE OF PBUC}

The econometric analysis of public expenditures in Latin America faces several drawbacks, spanning from restrictions on obtaining long homogeneous series to difficulties in modeling their dynamics. ${ }^{13}$ In order to analyze the presence of PBuCs in Argentina, Chile, Colombia, and Mexico over the 1982-2014 period, we have used data from the Government Finance Statistics elaborated by the International Monetary Fund (IMF) for the 1980-1989 period and from CEPALSTAT, published by the Economic Commission for Latin American and the Caribbean for 1990-2014 (CEPAL, 2015) $\cdot{ }^{14}$ All nominal figures have been deflated, and converted to real terms,

12 An autoregressive process is stationary if the roots of the lag polynomial $\mathrm{L}(\varnothing)=0$ are outside the unit circle. When this condition is fulfilled, it is possible to apply conventional estimation and inference methods (Johnston \& DiNardo, 1997).

13 According to Reyes and Mejía (2016), the public expenditure series exhibit atypical statistical features associated with the presence of anomalous values, which generates empirical distributions with an excess of kurtosis and usually a positive bias. They argue that these properties might be explained by the discretionary management of public accounts. Additionally, the lack of continuous and homogeneous series has led several authors to use different data sources (Nieto \& Santiso, 2012; Barberia \& Avelino, 2011).

14 The series from these two sources were chained by using 1990 as the year of reference. To account for the possibility of differentiated dynamics of the series over these two subsamples, a dichotomous variable is introduced 
using the GDP deflator for each of the four countries, published by the International Financial Statistics (IFS) of the IMF.

The growth rates of several components of real public expenditures are modeled according to expression (1). In order to apply conventional econometric models, the stationarity of the series was verified using common unit root tests. The econometric strategy consists of three steps. First, the order of the autoregressive component is identified and, second, the electoral variables are introduced; in the third step, dichotomous variables are added to capture the effects of anomalous values (outliers). ${ }^{15}$ In a few series of Argentina and Mexico, however, some outliers were removed in the first step since their very large values distorted the modelling process. Additionally, given that data come from different sources, a dichotomous variable (DAT) is added to distinguish between them. The specification of these final models is evaluated by using tests of autocorrelation, heteroscedasticity, normality, and functional form. ${ }^{16}$

The model estimations for all variables and countries are presented in Tables 1 to 12. In general, model specifications are adequate, although some issues of normality and functional form persist in some cases. Three different formulations of the model are estimated for each country, depending on the variable used to control for the effects of business cycles, as previously mentioned. ${ }^{17}$

The estimates for Argentina are shown in Tables 1 to 3. The first interesting result is that the GDP and public revenue growth rates are statistically significant in all models, except in the capital transfers and expenditure on goods and services models, respectively (Tables 1 and 2). In contrast, the GDP gap as a control variable is not statistically significant in any model (Table 2). Moreover, the estimated coefficients of the GDP growth rates are positive, which suggests that fiscal policy has been essentially pro-cyclical in this country over the period, as shown by other

in the model with a value of 0 up to 1989, and 1 from 1990 onwards, as done by Barberia and Avelino (2011). The variables analyzed for each country are described in Appendix 1.

15 If a residual is greater than three times its standard deviation, it is considered as an anomalous value and is removed by introducing a corresponding dummy variable. D1991, for example, denotes the dummy to remove an outlier occurring in 1991.

16 The residuals are tested for normality and specification errors by using the conventional Jarque-Bera (1987) and the Ramsey (1969) test, respectively. If the residuals of the model exhibit heteroscedasticity or heteroscedasticity and autocorrelation, standard errors are corrected by using the White (1980) and the Newey-West (1987) correction methods, respectively. In order to save space, the estimates of the specification and unit root tests are not reported, but they are available upon request.

17 In fact, in the preliminary estimations, GDP growth rates and public revenues were included as control variables in each model, but usually the latter were not statistically significant. 
studies, while the positive coefficients of the public revenue growth rate imply that this factor conditions the government's spending capacity.

In turn, the evidence of PBuCs is weak: the estimated coefficients of the dichotomous variables for election years or the previous year are not statistically significant, or they have the opposite sign to the one suggested by theory. However, some spending contractions are detected in the year after elections, especially when public revenues are incorporated as a control variable (Table 3), which is indeed consistent with the PBuC hypothesis. Although the effects of several outliers are estimated, they can be linked to electoral manipulation only in the case of the 1983 elections, in items such as subsidies and other current transfers. ${ }^{18}$

The estimates for Colombia are displayed in Tables 4 to 6. It is worth noting that GDP growth rates do not have a statistically significant relationship with the components of public expenditure, whereas the GDP gap is related to total and current expenditures. In turn, total revenues seem to explain expenditure on goods and services, as well as capital expenditure and acquisitions of fixed capital assets. ${ }^{19}$ The evidence of $\mathrm{PBuC}$ is partial, though there are some robust results to be highlighted: there is a statistically significant increase in expenditure on goods and services and, in two model specifications, in the acquisition of fixed capital assets during the year previous to elections, as well as a cutback in subsidies and other current transfers during the year following elections. The existing outliers in this case cannot be associated with elections or natural disasters. Our results, mainly those concerning fixed capital asset expenditures, are consistent with those reported by Drazen and Eslava (2003), who found a significant increase before and up to the period of elections. Overall, the emergence of PBuC in the Colombian case might be explained by the survival of some practices and political conflicts that have hindered the consolidation of the Colombian democratic system, such as political clientelism, drug trafficking, internal armed conflict, and erosion of weights and counterweights that are characteristic of mature democracies (Botero, Hoskin \& Pachón, 2010). This context offers

18 The presidential elections of 1983, associated to the Process of National Reorganization, mark the return of democracy in Argentina after the military dictatorship (Camou, 1995). Hence, the electoral manipulation of public spending might be explained by the inexperience of democratic system, as Canes-Wrone y Ponce de León (2015) suggest. The rest of anomalous values could be associated with natural disasters in 1985 and 1993 (Lavell, 2004). The latter, in fact, was removed before modelling the series of capital expenditure and capital transferences, as mentioned above.

19 In this case, the dichotomous variable utilized to account for differences in data sources was not significant in most of the models. 
incentives for policymakers to manipulate economic policy instruments to obtain electoral and partisan benefits, as Franzese and Jusko (2008) suggest. ${ }^{20}$

The results for Chile (Tables 7 to 9) indicate that public expenditure and its components are mildly associated with economic activity and public revenue indicators, providing only weak evidence of a pro-cyclical fiscal policy. There is no robust evidence of PBuCs along the lines of expansive policies before elections, though a subsequent adjustment is detected in the cases of total expenditure (but only at $10 \%$ of significance), capital expenditure, and the acquisition of fixed capital assets (at 5\%), as shown in the estimates of Tables 7 and 9. Regarding the outliers, the one identified for 1989 could be linked to the first election held after the military dictatorship, but the estimated coefficients of the corresponding dichotomous variables in the models of total and current expenditure are negative, probably caused by adjustments following the Tarapaca earthquake in 1987 (CSN, 2016) and the eruption of the Volcano Lonquimay in 1988 (Moreno \& Gardeweg, 1989).

Finally, estimations of PBuCs in Mexico are displayed in Tables 10 to 12. It should be emphasized that free general elections in this country were held only from 2000 on, while prior to that the competition to the party in power during several decades, the Institutional Revolutionary Party (PRI, for its acronym in Spanish), was rather limited (Velázquez, 2008). However, according to González (2002), the political competition has increased over time, especially since the elections of 1988, which may have motivated the authorities to engage in opportunistic practices, according to the view expressed by Brender and Drazen (2005). Therefore, the effects of elections on public expenditure could have been different before 2000 when the possibilities of fiscal manipulation were higher. On the contrary, once political competition increased further and other institutional conditions improved (divided government, change of party in power, more free media, and others), the use of public expenditure to gain votes could have become more difficult. ${ }^{21}$ In order to assess differences in the dynamics of public expenditure within these periods and the emergence of PBuCs, two sets of dichotomous electoral variables are introduced, defined according to expression (1):

20 The existing outliers in this case cannot be associated with elections or natural disasters. Elections were held in 1986 and 1990, thus some extraordinary rise in expenditure would be expectable. Moreover, in 1985, the volcano Nevado del Ruiz erupted, and between 1989 and 1992, a number of disasters occurred, among which there was another eruption of the Nevado, the overflowing of the San Carlos and Cauca Rivers, as well as an earthquake and a drought provoked by El Niño (Hermelin, 2005). Therefore, it is curious that anomalous values for 1985 and 1990 are negative.

21 Indeed, from 1997 to 2018, Mexico experienced a divided government, which may have brought about a better monitoring of public expenditure. The evidence, however, shows that the emergence of PBuCs has not been completely excluded (Reyes, Mejía \& Riguzzi, 2013). 
the first set accounts for the effects of elections on spending between 1982 and 1994, while the second one comprises those from 2000 to $2012 .{ }^{22}$

The results for the Mexican case point out that fiscal policy over the entire period was mainly pro-cyclical, but with several exceptions, since the estimated coefficient of business cycle indicators are not always statistically significant (Cuadra, 2008; Mejía, 2003; Reyes \& Mejía, 2012). The estimated coefficients of public revenues, however, are not statistically significant, suggesting that this variable is largely unimportant in the management of government expenditure.

Concerning PBuCs, the first set of electoral variables shows a significant rise in total expenditure before electoral years in each of the three model specifications. ${ }^{23}$ Some other items, like personal services, increase before election dates in some model specifications. Yet, these cannot be considered as robust results. Noteworthy is the fact that the estimated coefficients for electoral years are negative in some cases, opposite to the claims of the PBuC theory; this may be due to the time aggregation of the data, given that elections are held in the middle of the year. ${ }^{24}$ About post-electoral adjustments, a robust result points to a fall in public works expenditures, a variable highly sensitive to electoral manipulation, as suggested by Schuknecht (1996). ${ }^{25}$

On the other hand, the evidence of PBuCs in total expenditure becomes weaker after the 2000 elections since the electoral dummies are statistically significant only when GDP growth rates are used as a control variable. Nonetheless, there is some evidence of pre-electoral increases in variables such as current expenditure, personal services, and general and other services. Then, only few electoral variables seem to be statistically significant or have robust effects, possibly due to a better

22 Although the 1988 and 1994 elections were contested, in the end, the PRI maintained its hegemony by a wide margin. The share of votes received by this party was 50.4 and $48.7 \%$, respectively (Instituto Nacional Electoral, 2016).

23 Flores (2007), Magaloni (2000), and Reyes and Mejía (2016) also report results that are robust regarding the sign of the estimated coefficient in the case of total expenditure, with an increase occurring before the election period.

24 In this sense, the time aggregation problem affects Mexican data. Since elections are held during the first days of July, the aggregate figures of the electoral year combine the results of expansive pre-electoral policies with those resulting from restrictive post-electoral adjustments. The signs of the estimated coefficients suggest that the latter is greater than the former.

25 These results differ from those reported by Reyes and Mejía (2016), who argue that the high degree of discretionary management of public expenditures may explain the lack of statistical significance of their findings. However, they do not distinguish between the two political regimes considered here. 
Pablo Mejía Reyes • Marlen Rocio Reyes Hernández • Paolo Riguzzi

monitoring of public expenditures by the Chamber of Deputies in the framework of divided government, which is consistent with theory. ${ }^{26}$

\section{CONCLUSIONS}

This paper tests the presence of PBuCs in four important Latin American countries, searching for evidence around the presidential elections of Argentina, Chile, Colombia, and Mexico, over the 1982-2014 period. Extended autoregressive models have been estimated to model the growth rates of total public expenditure and its main components, incorporating electoral variables and controlling for the effects of business cycles on fiscal policy through several indicators.

As in other national cases, this phenomenon has been elusive. The results indicate that fiscal policies have been pro-cyclical, and provide weak support for the PBuC hypothesis, particularly for Argentina, on both counts. Nevertheless, for Colombia and Mexico (the latter before 2000), there is evidence of significant increase prior to elections in total expenditure, as well as in expenditure on goods and services, followed by cutbacks in components highly sensitive to political manipulation, such as subsidies and public works. These cuts are also recognizable in Chile regarding various components of public spending, mostly in capital expenditure and the acquisition of fixed capital assets.

By and large, our findings show how difficult it is to validate the electoral manipulation of expenditure, no matter how evident it may appear to many citizens, especially in some countries. Although the temporal aggregation resulting from the use of annual data might contribute to explaining these difficulties, the surge of PBuCs is a consequence of several political and economic factors that should be summed up as explanatory variables. However, statistical information to measure these is rarely available. The literature has underlined the role of institutional frameworks in budget negotiations between the executive and the legislative branches as a crucial issue for the emergence of PBuCs (Saporiti \& Streb, 2008). Of course, the degree of consolidation of the democratic system and other institutional arrangements play a

26 Neither the identified outliers, nor the fall in personal services in 1983 can be directly associated with electoral manipulation. The latter may have been part of the stabilization policy following the debt crisis of 1982, while the increase of several components of public expenditure can be explained by the damages caused by Hurricane Pauline in 1997. In fact, this outlier was removed previously to the modelling of current expenditure and personal services expenditure. 
central role in this, through the process of defining, executing, and supervising the use of public funds.

In this regard, we can say that democracy has evolved at a different pace in these four countries, which can partially explain our results. According to Polity IV (Marshall, Gurr \& Jaggers, 2014), Argentina and Colombia, on one hand, display a better and more stable democratic performance, although the latter still faces some obstacles for a full consolidation (Botero, Hoskin \& Pachón, 2010). On the other, Mexico holds a lower position (mainly due to the weakness of checks on its executive power), even if its institutions have significantly improved over the last two decades. Chile, in turn, has the best-qualified democracy in the group, despite that it began at a very low level. Overall, the development of democratic systems seems to have constrained the emergence of PBuCs in Argentina, Chile, and Mexico (since 2000), but less so in Colombia.

The evidence provided here needs to be supplemented by further research based on alternative empirical methods capable of incorporating the role of political factors together with economic mechanisms, as well as other forms of diverting public funds or providing fiscal exemptions to cronies. Further inquiry on these issues is relevant, not only because politicians' abuses of power might undermine the credibility of democratic institutions, but also because economic policies that deviate from welfare objectives generate social waste, which benefits only particular groups.

\section{REFERENCES}

1. Aboal, D., Lorenzo, F., \& Oddone G. (2001). The Political Economy of Budget Deficits in Uruguay. LACEA: Annual Conference, Montevideo.

2. Alesina, A. (1987). Macroeconomic policy in a two-party system as a repeated game. Quarterly Journal of Economics, 102 (3), 651-678.

3. Alesina, A. (1989). Politics and Business Cycles in Industrial Democracies. Economic Policy, 4(8), 57-98.

4. Alesina, A., \& Sachs, J. (1988). Political parties and the business cycle in the United States, 1948-1984. Journal of Money Credit and Banking, 20(1), 63-82.

5. Barberia, L.G., \& Avelino, G. (2011). Do Political Budget Cycles Differ in Latin American Democracies? Economía, 11(2), 101-134.

6. Borsani, H. (2003). Elecciones, gobiernos mayoritarios y resultados macroeconómicos en América Latina (1979-1998). Desarrollo Económico, 43(171), 389-412. 
7. Botero, F., Hoskin, G. W., \& Pachón, M. (2010). Sobre forma y sustancia: una evaluación de la democracia electoral en Colombia. Revista de Ciencia Política, 30(1), 41-64.

8. Brender, A., \& Drazen, A. (2003). Where does the political budget cycle really come from? CEPR Discussion Paper no. 4049.

9. Brender, A., \& Drazen, A. (2005). Political Budget Cycles in New Versus Established Democracies. Journal of Monetary Economics, 52 (7), 1271-1295.

10. Camou, A. (1995). Democracia y reforma económica en Argentina (1983-1995): ¿doce años no es nada? América Latina Hoy, 11(12), 97-104.

11. Canes-Wrone, B., \& Ponce de León, C. (2015). Electoral Cycles and Democratic Development. Submitted.

12. Centro Sismológico Nacional (CSN). (2016). Sismos Importantes y/o Destructivos (1570 a la fecha). Retrieved from www.sismologia.cl (consulted on January 21, 2016).

13. CEPAL (2015). Estadísticas e Indicadores Económicos. Retrieved from http://www. cepal.org (consulted on August 25, 2015).

14. Cuadra, G. (2008). Hechos estilizados del ciclo económico en México. Banco de México, Documento de investigación, núm. 2008-14, 1-54.

15. Cukierman, A., \& Meltzer, A. H. (1986). A positive theory of discretionary policy, the cost of a democratic government, and the benefits of a constitution. Economic Inquiry, 24(3), 367-388.

16. Drazen, A., \& Eslava, M. (2003). The political business cycle in Colombia on the National and Regional level. Archivos de Economía. Departamento Nacional de Planeación. Dirección de Estudios Económicos. Núm. 215.

17. Drazen, A. (2001). The Political Business Cycle after 25 Years. In Bernanke, B. S., \& Rogoff, K. (Eds.). NBER Macroeconomics Annual 2000 (pp. 75-138), Cambridge: The MIT Press.

18. Dubois, E. (2016). Political Business Cycles 40 Years after Nordhaus. Public Choice, 166(1-2), 235-259.

19. Flores, D. (2007). Elecciones y ciclos económicos en México. El Trimestre Económico, 74(2), 467-474.

20. Franzese, R. J., \& Jusko, K. L. (2008). Political-Economic Cycles. In Wittman, D. A., \& Weingast, B. R. (Eds.). The Oxford Handbook of Political Economy (pp. 546-565), Oxford: Oxford University Press.

21. Gavin, M., \& Perotti, R. (1997). Fiscal Policy in Latin America. In Bernanke, B., \& Rotemberg, J. (Eds.). NBER Macroeconomics Annual 1997 (pp. 11-72), Cambridge: MIT Press.

22. González, M. A. (2002). Do Changes in Democracy Affect the Political Budget Cycle? Evidence from Mexico. Review of Development Economics, 6(2), 204-224.

23. Grier, K. G. (1987). Presidential Elections and Federal Reserve Policy: An empirical test. Southern Economic Journal, 54(2), 475-486. 
24. Hermelin, M. (2005). Desastres de origen natural en Colombia 1979-2004, Medellin: EAFIT.

25. Hibbs, D. A. Jr. (1977). Political Parties and Macroeconomic Policy. American Political Science Review, 71(4), 1467-1487.

26. Hibbs, D. A. (2006). Voting and the Macroeconomy. In Wittman, D. A., \& Weingast, B. R. (Eds.). The Oxford Handbook of Political Economy (pp. 565-586), Oxford: Oxford University Press.

27. Hodrick, R. J., \& Prescott, E. C. (1997). Postwar U.S. Business Cycles: An Empirical Investigation. Journal of Money, Credit and Banking, 29(1), 1-16.

28. Huntington, S. P. (1993). The Third Wave. Democratization in the Late Twentieth Century. Norman, Oklahoma: University of Oklahoma Press.

29. Instituto Nacional Electoral. (2016). Estadísticas y Resultados Electorales. Retrieved from http://www.ine.mx/archivos3/portal/historico/contenido/Historico_de_ Resultados_Electorales/ (consulted on January 20th, 2016).

30. Jarque, C. M., \& Bera, A. K. (1987). A Test for Normality of Observations and Regression Residuals. International Statistical Review, 55, 163-172.

31. Johnston, J., \& DiNardo, J. (1997). Econometric Methods. New York: McGraw Hill, $4^{\text {th }}$ ed.

32. Kahneman, D. (2003). Maps of Bounded Rationality: Psychology for Behavorial Economics. American Economic Review, 93(5), 1449-1475.

33. Klomp, J., \& de Haan, J. (2013). Do political budget cycles really exist? Applied Economics, 45(3), 329-341.

34. Kraemer, M. (1997). Electoral Budget Cycles in Latin America and the Caribbean: Incidence, Causes, and Political Futility. Working Paper no. 354. Washington, DC: Inter-American Development Bank, Office of the Chief Economist.

35. Lavell, A. (2004). La Red de Estudios Sociales en Prevención de Desastres en América Latina. LA RED: Antecedentes, Formación y Contribución al Desarrollo de los Conceptos, Estudios y la Práctica en el Tema de los Riesgos y Desastres en América Latina: 1980-2004. San José de Costa Rica: FLACSO-LA RED. Retrieved from http:// www.desenredando.org/public/varios/2004/LARED-AFCDCEPTRDAM/LARED/ AFCDCEPTRDAM_nov-26-2004.pdf (consulted on January 25th, 2016)

36. Lucas, R. E. Jr. (1972). Expectations and the neutrality of money. Journal of Economic Theory, 4(2), 103-124.

37. Lucas, R. E. Jr. (1977). Understanding Business Cycles. Carnegie-Rochester Conference Series on Public Policy, 5(1), 7-29.

38. McCallum, B. (1978). The political business cycle: an empirical test. Southern Economic Journal, 44(3), 504-515.

39. Magaloni, B. (2000). Institutions, Political Opportunism, and Macroeconomic Cycles: Mexico, 1970-1998. Working Paper. Stanford University. 
Pablo Mejía Reyes • Marlen Rocio Reyes Hernández • Paolo Riguzzi

40. Mainwaring, S., \& Pérez Liñán, A. (2006). Latin American Democratization Since 1978: Democratic Transitions, Breakdowns and Erosions. In Hagopian, F., \& Mainwaring. S. (Eds.). The Third Wave of Democratization in Latin America. Advances and Setbacks (pp. 14-60), Cambridge; Cambridge University Press.

41. Marshall, M. G, Gurr, T. R., \& Jaggers, K. (2014). Polity IV Project: Dataset Users' Manual. Center for Systemic Peace.

42. Mejía, P. (2003). Regularidades empíricas en los ciclos económicos de México: producción, inversión, inflación y balanza comercial. Economía mexicana, XII(2), 231-269.

43. Moreno, H., \& Gardeweg, M. C. (1989). La erupción reciente en el Complejo Volcánico Lonquimay (diciembre 1988), Andes del Sur. Revista Geológica de Chile, 16(11), 93-117.

44. Newey, W. K., \& West, K. D. (1987). A Simple, Positive Semi-Definite, Heteroskedasticity and Autocorrelation Consistent Covariance Matrix. Econometrica, 55(3), 703-708.

45. Nieto-Parra, S., \& Santiso, J. (2012). Revisiting Political Budget Cycles in Latin America. In Santiso, J., \& Dayton-Johnson, J. (Eds.). The Oxford Handbook of Latin American Political Economy. New York: Oxford University Press.

46. Nordhaus, W. D. (1975). The political business cycle. Review of Economic Studies, $42(2), 169-190$.

47. North, D. C. (2005). Understanding the Process of Economic Change. Princeton University Press.

48. North, D. C., Wallis, J. J., \& Weingast, B. R. (2009). Violence and Social Orders: A Conceptual Framework for Interpreting Recorded Human History. New York: Cambridge University Press.

49. Ogura, L. M. (2000). Political Business Cycles in the Brazilian Economy. Monography. University of Brasilia.

50. Olters, J. P. (2012). Political Business Cycle. In Besomi, D. (Ed.). Crises and Cycles in Economic Dictionaries and Encyclopedias (pp. 463-484), New York, NY: Routledge.

51. Osborn, D. R., Pérez, P. J., \& Sensier, M. (2005). Business Cycle Linkages for the G7 Countries: Does the US Lead the World? Economics Discussion Paper Series no. 0527. The University of Manchester.

52. Payne, M., Zovatto, D., Carrillo, F., \& Allamand, F. (2006). La política importa. Democracia y desarrollo en América Latina. Banco Interamericano de Desarrollo.

53. Pepinsky, T. (2007). Autocracy, Elections, and Fiscal Policy: Evidence from Malaysia. Studies in Comparative International Development, 42(1), 136-163.

54. Persson, T., \& Tabellini, G. E. (1990). Macroeconomic Policy Credibility and Politics. Malaysia: Harwood Academic Publishers.

55. Persson, T., \& Tabellini, G. E. (2000). Political Economics: Explaining Economic Policy. Cambridge, Massachusetts: The MIT Press.

56. Remmer, K. L. (1993). The Political Economy of Elections in Latin America, 19801991. The American Political Science Review, 87(2), 393-407. 
57. Ramsey, J. B. (1969). Tests for Specification Error in Classical Linear Least Squares Analysis. Journal of the Royal Statistical Society, Series B, 31, 350-371.

58. Reyes, M. R., \& Mejía, P. (2012). Co-movimiento de los componentes del gasto público y el ciclo económico en México, 1980-2007. Explanans, 1(2), 53-88.

59. Reyes, M. R., Mejía, P., \& Riguzzi, P. (2013). Ciclo político presupuestal y gobiernos con y sin mayoría en México, 1994 y 2006. Economía, Sociedad y Territorio, XIII(41), 79-119.

60. Reyes, M. R., \& Mejía, P. (2016). Ciclo político presupuestal en México, 1980-2014: un enfoque econométrico. Gestión y Política Pública, XXV(2), 415-445.

61. Rogoff, K. (1990). Equilibrium Political Budget Cycles. American Economic Review, $80(1), 21-36$.

62. Rogoff, K., \& Sibert, A. (1988). Elections and Macroecomic Policy Cycles. The Review of Economic Studies, 55(1), 1-16.

63. Romer, D. (2006). Macroeconomía avanzada. Madrid: McGraw Hill.

64. Santiso, C. (2007). Parliaments and budgeting: Understanding the politics of Budget. In Bodemer, K., \& Carrillo, F. (Eds.). Gobernabilidad y reforma política en América Latina y Europa (pp. 135-186), La Paz, Bolivia: GIGA, BID, REDGOB-Plural Editores.

65. Saporiti, A., \& Streb, J. M. (2008). Separation of Powers and Political Budget Cycles. Public Choice, 137(1-2), 329-345.

66. Sherman, H. J. (1991). The Business Cycle: Growth and Crisis under Capitalism. Princeton University Press.

67. Schuknecht, L. (1996). Political Business Cycles and Fiscal Policies in Developing Countries. Kyklos, 49(2), 155-170.

68. Shi, M., \& Svensson, J. (2000). Conditional Political Business Cycle: Theory and Evidence. mimeo, Institute for International Economic Studies. Stockholm: Stockholm University.

69. Shi, M., \& Svensson, J. (2002). Conditional political budget cycles. CEPR Discussion Paper no. 3352.

70. Shi, M., \& Svensson, J. (2003). Political Budget Cycles: A Review of Recent Developments. Nordic Journal of Political Economy, 29(1), 67-76.

71. Shi, M., \& Svensson, J. (2006). Political Budget Cycles: Do They Differ Across Countries and Why? Journal of Public Economics, 90(8-9), 1367-1389.

72. Smith, P. H. (2012). Democracy in Latin America: Political Change in Comparative Perspective. Oxford: Oxford University Press.

73. Streb, J. M., Lema, D., \& Garofalo, P. (2012). Temporal aggregation in political budget cycles. Economía, 13(1), 39-78.

74. Talvi, E., \& Végh, C. A. (2005). Tax Base Variability and Procyclical Fiscal Policy in Developing Countries. Journal of Development Economics, 78(1), 156-190.

75. Taylor, S. L. (2009). Voting Amid Violence: Electoral Democracy in Colombia. Boston: Northeastern University Press. 
Pablo Mejía Reyes • Marlen Rocio Reyes Hernández • Paolo Riguzzi

76. Tufte, E. R. (1978). Political Control of the Economy. Princeton: Princeton University Press.

77. Velázquez, R. (2008). La relación entre el Ejecutivo y el Congreso en materia de política exterior durante el sexenio de Vicente Fox: icooperación o conflicto? Política y Gobierno, XV(1), 113-155.

78. Weatherford, S. (1987). The interplay of ideology and advice in economic policymaking: the case of political business cycles. The Journal of Politics, 49(4), 925-952.

79. White, H. (1980). A Heteroscedasticity-consistent Covariance Matrix Estimator and a Direct Test for Heteroscedasticity. Econometrica, 48, 817-838. 


\section{APPENDIX 1. CHARACTERISTICS AND SOURCES OF ANALYZED VARIABLES BY COUNTRY}

\begin{tabular}{|c|c|}
\hline Variable & Concept \\
\hline TGTAR & Argentina's total expenditure \\
\hline TGCAR & Argentina's current expenditure \\
\hline TGBSAR & Argentina's expenditure on goods and services \\
\hline TSTAR & Argentina's subsidies and other current transferences \\
\hline TGKAR & Argentina's capital expenditure \\
\hline TKFAR & Argentina's acquisition of fixed capital assets \\
\hline TTKAR & Argentina's capital transferences \\
\hline TPIBAR & Argentina's real GDP growth rate \\
\hline TITAR & Argentina's total government revenues \\
\hline TGTCH & Chile's total expenditure \\
\hline TGCCH & Chile's current expenditure \\
\hline TGBSCH & Chile's expenditure on goods and services \\
\hline TGKCH & Chile's capital expenditure \\
\hline TKFCH & Chile's acquisition of fixed capital assets \\
\hline TTKCH & Chile's capital transferences \\
\hline TPIBCH & Chile's real GDP growth rate \\
\hline TITCH & Chile's total government revenues \\
\hline TGTCO & Colombia's total expenditure \\
\hline TGCCO & Colombia's current expenditure \\
\hline TGBSCO & Colombia's expenditure on goods and services \\
\hline TSTCO & Colombia's subsidies and other current transferences \\
\hline TGKCO & Colombia's capital expenditure \\
\hline TKFCO & Colombia's acquisition of fixed capital assets \\
\hline TPIBCO & Colombia's real GDP growth rate index \\
\hline TITCO & Colombia's total government revenues \\
\hline TGTMEX & Mexico's total expenditure \\
\hline TGPMEX & Mexico's programmable expenditure \\
\hline TGCMEX & Mexico's current expenditure \\
\hline TSPMEX & Mexico's personal services \\
\hline TMSMEX & Mexico's materials and supplies \\
\hline TSGMEX & Mexico's general and other services \\
\hline TGKMEX & Mexico's capital expenditure \\
\hline TBMIMEX & Mexico's movable and immovable property \\
\hline TOPMEX & Mexico's public works \\
\hline TIFMEX & Mexico's physical investment \\
\hline TSTMEX & Mexico's subsidies and transferences \\
\hline TGNPMEX & Mexico's non-programmable expenditure \\
\hline TPIBMEX & Mexico's real GDP growth rate \\
\hline TITMEX & Mexico's total government revenues \\
\hline
\end{tabular}

Data from 1980 to 1990 were collected from the IMF's Government Finance Statistics yearbooks and for the 1990-2014 period from the CEPALSTAT database of ECLAC, in the government operations section, except for Mexico, whose data were obtained from the Bank of Mexico (BANXICO). The GDP real index and total government revenues were obtained from the International Financial Statistics (IFS) of the IMF. To combine data from the two sources, the series were chained from 1990. As already stated, the nominal figures were deflated by using the GDP deflator as published in the IFS. 
Pablo Mejía Reyes • Marlen Rocio Reyes Hernández • Paolo Riguzzi

Table 1.

Econometric estimation of PBUC in Argentina controlling by the GDP growth rate, 1982-2014

\begin{tabular}{|c|c|c|c|c|c|c|c|}
\hline Expenditure & Total & $\begin{array}{c}\text { Current } \\
\text { expenditure }\end{array}$ & $\begin{array}{c}\text { Expenditure } \\
\text { on goods and } \\
\text { services }\end{array}$ & $\begin{array}{l}\text { Subsidies and } \\
\text { other current } \\
\text { transferences }\end{array}$ & $\begin{array}{c}\text { Capital } \\
\text { expenditure*\# }\end{array}$ & $\begin{array}{c}\text { Acquisition } \\
\text { of fixed } \\
\text { capital } \\
\text { assets }\end{array}$ & $\begin{array}{c}\text { Capital } \\
\text { transferences }\end{array}$ \\
\hline Intercept & $\begin{array}{c}-10.293 \\
(0.027)\end{array}$ & $\begin{array}{l}-9.655 \\
(0.026)\end{array}$ & $\begin{array}{l}-4.180 \\
(.393)\end{array}$ & $\begin{array}{l}-12.995 \\
(0.015)\end{array}$ & $\begin{array}{l}-17.370 \\
(0.000)\end{array}$ & $\begin{array}{c}-5.001 \\
(0.696)\end{array}$ & $\begin{array}{c}-3.525 \\
(0.856)\end{array}$ \\
\hline$c$ & $\begin{array}{c}1.194 \\
(0.002)\end{array}$ & $\begin{array}{c}1.158 \\
(0.001)\end{array}$ & $\begin{array}{c}1.301 \\
(0.003)\end{array}$ & $\begin{array}{c}1.107 \\
(0.008)\end{array}$ & $\begin{array}{c}2.454 \\
(0.000)\end{array}$ & $\begin{array}{c}3.799 \\
(0.001)\end{array}$ & $\begin{array}{c}0.577 \\
(0.682)\end{array}$ \\
\hline$e_{\tau-1}$ & $\begin{array}{r}-11.213 \\
(0.034)\end{array}$ & $\begin{array}{c}-10.728 \\
(0.029)\end{array}$ & $\begin{array}{c}-9.284 \\
(0.123)\end{array}$ & $\begin{array}{r}-10.902 \\
(0.058)\end{array}$ & $\begin{array}{l}-3.960 \\
(0.448)\end{array}$ & $\begin{array}{c}-2.312 \\
(0.874)\end{array}$ & $\begin{array}{l}-15.351 \\
(0.365)\end{array}$ \\
\hline$e_{\tau}$ & $\begin{array}{c}0.102 \\
(0.984)\end{array}$ & $\begin{array}{c}3.183 \\
(0.498)\end{array}$ & $\begin{array}{c}-8.540 \\
(0.154)\end{array}$ & $\begin{array}{c}1.177 \\
(0.841)\end{array}$ & $\begin{array}{l}-11.591 \\
(0.234)\end{array}$ & $\begin{array}{c}-8.208 \\
(0.571)\end{array}$ & $\begin{array}{c}-30.113 \\
(0.096)\end{array}$ \\
\hline$e_{\tau+1}$ & $\begin{array}{l}-7.409 \\
(0.151)\end{array}$ & $\begin{array}{l}-6.159 \\
(0.198)\end{array}$ & $\begin{array}{l}-9.149 \\
(0.131)\end{array}$ & $\begin{array}{c}-6.880 \\
(0.223)\end{array}$ & $\begin{array}{l}-11.940 \\
(0.015)\end{array}$ & $\begin{array}{c}-16.914 \\
(0.251)\end{array}$ & $\begin{array}{c}1.883 \\
(0.910)\end{array}$ \\
\hline$D A T$ & $\begin{array}{c}18.767 \\
(0.000)\end{array}$ & $\begin{array}{c}16.748 \\
(0.000)\end{array}$ & $\begin{array}{c}11.598 \\
(0.034)\end{array}$ & $\begin{array}{l}21.966 \\
(0.000)\end{array}$ & $\begin{array}{l}21.064 \\
(0.000)\end{array}$ & $\begin{array}{c}9.383 \\
(0.474)\end{array}$ & $\begin{array}{l}23.067 \\
(0.093)\end{array}$ \\
\hline D1981 & & & & & & & $\begin{array}{c}361.602 \\
(0.000)\end{array}$ \\
\hline D1983 & & & & $\begin{array}{c}65.682 \\
(0.000)\end{array}$ & & & \\
\hline D1985 & $\begin{array}{l}65.644 \\
(0.000)\end{array}$ & $\begin{array}{l}65.616 \\
(0.000)\end{array}$ & & $\begin{array}{c}98.528 \\
(0.000)\end{array}$ & $\begin{array}{l}72.804 \\
(0.000)\end{array}$ & & \\
\hline D1991 & & & & & $\begin{array}{c}-123.494 \\
(0.000)\end{array}$ & & \\
\hline D2004 & & & & & $\begin{array}{l}83.169 \\
(0.000)\end{array}$ & & \\
\hline D2014 & & & & & $\begin{array}{r}63.921 \\
(0.000)\end{array}$ & & \\
\hline$R^{2}$ & 0.716 & 0.731 & 0.503 & 0.806 & 0.882 & 0.440 & 0.791 \\
\hline
\end{tabular}

Figures in parenthesis are $p$-values. $D A T$ denotes a dichotomous variable to capture differences attributed to changing the source of data from 1990 on, while $D X$ refers to a dichotomous variable that seeks to remove outliers present in year $X$. The model specification tests are available upon request. * Heteroskedasticity and autocorrelation consistent standard errors (Newey-West correction). ${ }^{* *}$ Heteroskedasticity consistent standard errors (White correction). "An outlier present in 1993 was removed previously to the modelling of the dependent variable.

Source: authors' elaboration based on data from IMF (various) and ECLAC (2015). 
Table 2.

Econometric estimation of PBuC in Argentina controlling by the GDP gap, 1982-2014

\begin{tabular}{|c|c|c|c|c|c|c|c|}
\hline Expenditure & Total & $\begin{array}{c}\text { Current } \\
\text { expenditure }\end{array}$ & $\begin{array}{l}\text { Expenditure } \\
\text { on goods } \\
\text { and services }\end{array}$ & $\begin{array}{l}\text { Subsidies and } \\
\text { other current } \\
\text { transferences }\end{array}$ & $\begin{array}{c}\text { Capital } \\
\text { expenditure }^{* \#}\end{array}$ & $\begin{array}{c}\text { Acquisition } \\
\text { of fixed } \\
\text { capital } \\
\text { assets }\end{array}$ & $\begin{array}{l}\text { Capital } \\
\text { transferences }\end{array}$ \\
\hline Intercept & $\begin{array}{l}-9.350 \\
(0.076)\end{array}$ & $\begin{array}{c}-8.741 \\
(0.078)\end{array}$ & $\begin{array}{c}-4.477 \\
(0.432)\end{array}$ & $\begin{array}{l}-12.661 \\
(0.034)\end{array}$ & $\begin{array}{c}4.483 \\
(0.669)\end{array}$ & $\begin{array}{c}4.658 \\
(0.755)\end{array}$ & $\begin{array}{c}-3.272 \\
(0.830)\end{array}$ \\
\hline$c$ & $\begin{array}{l}53.004 \\
(0.140)\end{array}$ & $\begin{array}{r}52.008 \\
(0.124)\end{array}$ & $\begin{array}{l}28.143 \\
(0.504)\end{array}$ & $\begin{array}{l}24.123 \\
(0.530)\end{array}$ & $\begin{array}{l}10.918 \\
(0.899)\end{array}$ & $\begin{array}{l}-82.388 \\
(0.425)\end{array}$ & $\begin{array}{l}-5.352 \\
(0.959)\end{array}$ \\
\hline$e_{\tau-1}$ & $\begin{array}{l}-13.541 \\
(0.026)\end{array}$ & $\begin{array}{l}-12.986 \\
(0.023)\end{array}$ & $\begin{array}{c}-11.166 \\
(0.111)\end{array}$ & $\begin{array}{c}-13.034 \\
(0.046)\end{array}$ & $\begin{array}{r}-17.171 \\
(0.187)\end{array}$ & $\begin{array}{l}-16.280 \\
(0.359)\end{array}$ & $\begin{array}{r}-16.377 \\
(0.343)\end{array}$ \\
\hline$e_{\tau}$ & $\begin{array}{l}-1.085 \\
(0.851)\end{array}$ & $\begin{array}{c}2.036 \\
(0.708)\end{array}$ & $\begin{array}{l}-9.330 \\
(0.179)\end{array}$ & $\begin{array}{c}-0.883 \\
(0.894)\end{array}$ & $\begin{array}{c}-22.958 \\
(0.046)\end{array}$ & $\begin{array}{c}-15.448 \\
(0.347)\end{array}$ & $\begin{array}{c}-30.746 \\
(0.081)\end{array}$ \\
\hline$e_{\tau+1}$ & $\begin{array}{l}-8.796 \\
(0.138)\end{array}$ & $\begin{array}{c}-7.498 \\
(0.177)\end{array}$ & $\begin{array}{c}-10.392 \\
(0.140)\end{array}$ & $\begin{array}{l}-8.455 \\
(0.187)\end{array}$ & $\begin{array}{l}-26.153 \\
(0.014)\end{array}$ & $\begin{array}{l}-22.680 \\
(0.172)\end{array}$ & $\begin{array}{c}1.028 \\
(0.952)\end{array}$ \\
\hline$D A T$ & $\begin{array}{c}23.211 \\
(0.000)\end{array}$ & $\begin{array}{l}21.055 \\
(0.000)\end{array}$ & $\begin{array}{l}17.477 \\
(0.005)\end{array}$ & $\begin{array}{l}26.889 \\
(0.000)\end{array}$ & $\begin{array}{l}26.997 \\
(0.008)\end{array}$ & $\begin{array}{c}14.341 \\
(0.342)\end{array}$ & $\begin{array}{l}25.466 \\
(0.093)\end{array}$ \\
\hline D1981 & & & & & & & $\begin{array}{c}358.231 \\
(0.000)\end{array}$ \\
\hline D1983 & & & & $\begin{array}{l}71.686 \\
(0.000)\end{array}$ & & & \\
\hline D1985 & $\begin{array}{l}58.842 \\
(0.000)\end{array}$ & $\begin{array}{l}59.049 \\
(0.000)\end{array}$ & & $\begin{array}{l}91.613 \\
(0.000)\end{array}$ & & & \\
\hline D1991 & & & & & $\begin{array}{c}-115.809 \\
(0.000)\end{array}$ & & \\
\hline D2004 & & & & & $\begin{array}{c}101.416 \\
(0.000)\end{array}$ & & \\
\hline$g_{k t-1}$ & & & & & & $\begin{array}{c}0.489 \\
(0.011)\end{array}$ & \\
\hline$R^{2}$ & 0.623 & 0.635 & 0.326 & 0.748 & 0.654 & 0.317 & 0.789 \\
\hline
\end{tabular}

Figures in parenthesis are p-values. DAT denotes a dichotomous variable to capture differences attributed to changing the source of data from 1990 on, while DX refers to a dichotomous variable that seeks to remove outliers present in year $\mathrm{X}$. The model specification tests are available upon request. * Heteroskedasticity consistent standard errors (White correction). \# An outlier present in 1993 was removed previously to the modelling of the dependent variable. Source: authors' elaboration based on data from IMF (various) and ECLAC (2015). 
Pablo Mejía Reyes • Marlen Rocio Reyes Hernández • Paolo Riguzzi

Table 3.

Econometric estimation of PBuC in Argentina controlling by total government revenues, 1982-2014

\begin{tabular}{|c|c|c|c|c|c|c|c|}
\hline Expenditure & Total & $\begin{array}{c}\text { Current } \\
\text { expenditure }\end{array}$ & $\begin{array}{l}\text { Expenditure } \\
\text { on goods } \\
\text { and services }\end{array}$ & $\begin{array}{l}\text { Subsidies and } \\
\text { other current } \\
\text { transferences }\end{array}$ & $\begin{array}{c}\text { Capital } \\
\text { expenditure }^{\#}\end{array}$ & $\begin{array}{c}\text { Acquisition of } \\
\text { fixed capital } \\
\text { assets }\end{array}$ & $\begin{array}{c}\text { Capital } \\
\text { transferences }^{\#}\end{array}$ \\
\hline Intercept & $\begin{array}{c}1.007 \\
(0.797)\end{array}$ & $\begin{array}{c}-2.262 \\
(0.612)\end{array}$ & $\begin{array}{c}1.249 \\
(0.813)\end{array}$ & $\begin{array}{c}-4.998 \\
(0.246)\end{array}$ & $\begin{array}{c}-3.915 \\
(0.656)\end{array}$ & $\begin{array}{c}-0.396 \\
(0.978)\end{array}$ & $\begin{array}{c}-5.159 \\
(0.695)\end{array}$ \\
\hline$i_{t}^{\&}$ & $\begin{array}{c}0.766 \\
(0.000)\end{array}$ & $\begin{array}{c}0.518 \\
(0.001)\end{array}$ & $\begin{array}{c}0.178 \\
(0.257)\end{array}$ & $\begin{array}{c}0.742 \\
(0.000)\end{array}$ & $\begin{array}{c}0.713 \\
(0.013)\end{array}$ & $\begin{array}{c}0.884 \\
(0.036)\end{array}$ & $\begin{array}{c}1.245 \\
(0.003)\end{array}$ \\
\hline$e_{\tau-1}$ & $\begin{array}{c}-10.859 \\
(0.025)\end{array}$ & $\begin{array}{l}-10.916 \\
(0.027)\end{array}$ & $\begin{array}{l}-12.186 \\
(0.058)\end{array}$ & $\begin{array}{l}-9.154 \\
(0.044)\end{array}$ & $\begin{array}{c}-9.164 \\
(0.390)\end{array}$ & $\begin{array}{l}-5.027 \\
(0.768)\end{array}$ & $\begin{array}{c}2.847 \\
(0.855)\end{array}$ \\
\hline$e_{\tau}$ & $\begin{array}{l}-4.697 \\
(0.293)\end{array}$ & $\begin{array}{c}-0.231 \\
(0.960)\end{array}$ & $\begin{array}{l}-11.892 \\
(0.054)\end{array}$ & $\begin{array}{l}-2.559 \\
(0.564)\end{array}$ & $\begin{array}{r}-20.613 \\
(0.047)\end{array}$ & $\begin{array}{l}-10.897 \\
(0.475)\end{array}$ & $\begin{array}{l}-27.038 \\
(0.072)\end{array}$ \\
\hline$e_{\tau+1}$ & $\begin{array}{l}-10.946 \\
(0.019)\end{array}$ & $\begin{array}{c}-8.884 \\
(0.060)\end{array}$ & $\begin{array}{r}-12.332 \\
(0.047)\end{array}$ & $\begin{array}{c}-9.240 \\
(0.036)\end{array}$ & $\begin{array}{c}-22.559 \\
(0.041)\end{array}$ & $\begin{array}{l}-18.177 \\
(0.239)\end{array}$ & $\begin{array}{c}4.249 \\
(0.773)\end{array}$ \\
\hline$D A T$ & $\begin{array}{c}8.856 \\
(0.028)\end{array}$ & $\begin{array}{l}11.777 \\
(0.014)\end{array}$ & $\begin{array}{l}11.847 \\
(0.029)\end{array}$ & $\begin{array}{l}14.413 \\
(0.003)\end{array}$ & $\begin{array}{l}18.491 \\
(0.040)\end{array}$ & $\begin{array}{l}10.678 \\
(0.447)\end{array}$ & $\begin{array}{l}15.101 \\
(0.243)\end{array}$ \\
\hline D1983 & & & & $\begin{array}{l}68.894 \\
(0.000)\end{array}$ & & & \\
\hline D1985 & & $\begin{array}{l}25.930 \\
(0.052)\end{array}$ & & $\begin{array}{l}48.098 \\
(0.000)\end{array}$ & & & \\
\hline D1991 & & & & & $\begin{array}{l}-97.097 \\
(0.000)\end{array}$ & & \\
\hline D2004 & & & & & $\begin{array}{c}98.122 \\
(0.000)\end{array}$ & & \\
\hline$g_{k t-1}$ & & & & & & $\begin{array}{c}0.390 \\
(0.022)\end{array}$ & $\begin{array}{l}-0.089 \\
(0.288)\end{array}$ \\
\hline$R^{2}$ & 0.755 & 0.732 & 0.387 & 0.885 & 0.739 & 0.414 & 0.476 \\
\hline
\end{tabular}

Figures in parenthesis are $p$-values. $D A T$ denotes a dichotomous variable to capture differences attributed to changing the source of data from 1990 on, while $D X$ refers to a dichotomous variable that seeks to remove outliers present in year $X$. The model specification tests are available upon request. ${ }^{\#}$ An outlier present in 1993 was removed previously to the modelling of the dependent variable. ${ }^{\&}$ Outliers present in 1989 and 1990 in the series of public revenues, $i$, were removed previously to the modelling of the dependent variable.

Source: authors elaboration based on data from IMF (various) and ECLAC (2015). 
Table 4.

Econometric estimation of PBUC in Colombia controlling by the GDP growth rate, 1982-2014

\begin{tabular}{|c|c|c|c|c|c|c|}
\hline Expenditure & Total & $\begin{array}{c}\text { Current } \\
\text { expenditure }\end{array}$ & $\begin{array}{l}\text { Expenditure } \\
\text { on goods and } \\
\text { services }\end{array}$ & $\begin{array}{l}\text { Subsidies and } \\
\text { other current } \\
\text { transferences }\end{array}$ & $\begin{array}{c}\text { Capital } \\
\text { expenditure }\end{array}$ & $\begin{array}{c}\text { Acquisition } \\
\text { of fixed } \\
\text { capital assets }\end{array}$ \\
\hline Intercept & $\begin{array}{c}7.535 \\
(0.083)\end{array}$ & $\begin{array}{c}6.868 \\
(0.058)\end{array}$ & $\begin{array}{c}-8.679 \\
(0.124)\end{array}$ & $\begin{array}{l}14.620 \\
(0.001)\end{array}$ & $\begin{array}{l}-2.600 \\
(0.702)\end{array}$ & $\begin{array}{l}-7.381 \\
(0.472)\end{array}$ \\
\hline$c$ & $\begin{array}{c}0.374 \\
(0.312)\end{array}$ & $\begin{array}{c}0.338 \\
(0.299)\end{array}$ & $\begin{array}{c}0.556 \\
(0.280)\end{array}$ & $\begin{array}{c}0.285 \\
(0.430)\end{array}$ & $\begin{array}{c}1.081 \\
(0.092)\end{array}$ & $\begin{array}{c}0.520 \\
(0.581)\end{array}$ \\
\hline elect $_{\tau-1}$ & $\begin{array}{c}-3.942 \\
(0.375)\end{array}$ & $\begin{array}{l}-5.451 \\
(0.153)\end{array}$ & $\begin{array}{l}17.289 \\
(0.006)\end{array}$ & $\begin{array}{l}-0.446 \\
(0.917)\end{array}$ & $\begin{array}{l}-2.662 \\
(0.715)\end{array}$ & $\begin{array}{l}17.246 \\
(0.123)\end{array}$ \\
\hline elect $_{\tau}$ & $\begin{array}{c}-9.261 \\
(0.049)\end{array}$ & $\begin{array}{l}-2.500 \\
(0.520)\end{array}$ & $\begin{array}{c}4.191 \\
(0.483)\end{array}$ & $\begin{array}{l}-6.800 \\
(0.123)\end{array}$ & $\begin{array}{l}-11.738 \\
(0.117)\end{array}$ & $\begin{array}{c}-12.926 \\
(0.246)\end{array}$ \\
\hline elect $_{\tau+1}$ & $\begin{array}{l}-4.729 \\
(0.281)\end{array}$ & $\begin{array}{l}-2.789 \\
(0.470)\end{array}$ & $\begin{array}{c}4.249 \\
(0.486)\end{array}$ & $\begin{array}{l}-9.189 \\
(0.040)\end{array}$ & $\begin{array}{c}0.439 \\
(0.953)\end{array}$ & $\begin{array}{c}8.386 \\
(0.457)\end{array}$ \\
\hline$D A T$ & $\begin{array}{c}6.385 \\
(0.093)\end{array}$ & $\begin{array}{c}1.701 \\
(0.567)\end{array}$ & $\begin{array}{c}4.423 \\
(0.346)\end{array}$ & $\begin{array}{l}-3.651 \\
(0.294)\end{array}$ & $\begin{array}{l}10.192 \\
(0.084)\end{array}$ & $\begin{array}{c}7.465 \\
(0.389)\end{array}$ \\
\hline D1990 & & $\begin{array}{r}-34.599 \\
(0.000)\end{array}$ & & & & \\
\hline$g_{k t-1}$ & $\begin{array}{c}-0.493 \\
(0.008)\end{array}$ & & & & & \\
\hline$g_{k t-2}$ & $\begin{array}{c}-0.351 \\
(0.052)\end{array}$ & & & & & \\
\hline$R^{2}$ & 0.412 & 0.456 & 0.318 & 0.612 & 0.242 & 0.260 \\
\hline
\end{tabular}

Figures in parenthesis are $p$-values. $D A T$ denotes a dichotomous variable to capture differences attributed to changing the source of data from 1990 on, while $D X$ refers to a dichotomous variable that seeks to remove outliers present in year $X$. The model specification tests are available upon request. Source: authors' elaboration based on data from IMF (various) and ECLAC (2015). 
Pablo Mejía Reyes • Marlen Rocio Reyes Hernández • Paolo Riguzzi

Table 5.

Econometric estimation of PBuC in Colombia controlling by the GDP gap, 1982-2014

\begin{tabular}{|c|c|c|c|c|c|c|}
\hline Expenditure & Total & $\begin{array}{c}\text { Current } \\
\text { expenditure }\end{array}$ & $\begin{array}{l}\text { Expenditure } \\
\text { on goods and } \\
\text { services }\end{array}$ & $\begin{array}{l}\text { Subsidies and } \\
\text { other current } \\
\text { transferences }\end{array}$ & $\begin{array}{c}\text { Capital } \\
\text { expenditure }\end{array}$ & $\begin{array}{l}\text { Acquisition of } \\
\text { fixed capital } \\
\text { assets }\end{array}$ \\
\hline Intercept & $\begin{array}{c}9.774 \\
(0.005)\end{array}$ & $\begin{array}{c}9.878 \\
(0.009)\end{array}$ & $\begin{array}{c}-8.112 \\
(0.160)\end{array}$ & $\begin{array}{l}15.798 \\
(0.000)\end{array}$ & $\begin{array}{c}-0.872 \\
(0.904)\end{array}$ & $\begin{array}{c}-6.548 \\
(0.527)\end{array}$ \\
\hline$c$ & $\begin{array}{l}55.705 \\
(0.017)\end{array}$ & $\begin{array}{l}53.023 \\
(0.037)\end{array}$ & $\begin{array}{c}-10.713 \\
(0.793)\end{array}$ & $\begin{array}{l}34.694 \\
(0.221)\end{array}$ & $\begin{array}{c}6.435 \\
(0.901)\end{array}$ & $\begin{array}{c}3.154 \\
(0.966)\end{array}$ \\
\hline elect $_{\tau-1}$ & $\begin{array}{c}-2.702 \\
(0.401)\end{array}$ & $\begin{array}{l}-4.019 \\
(0.257)\end{array}$ & $\begin{array}{l}18.645 \\
(0.004)\end{array}$ & $\begin{array}{c}-0.215 \\
(0.959)\end{array}$ & $\begin{array}{c}-0.292 \\
(0.969)\end{array}$ & $\begin{array}{c}18.386 \\
(0.097)\end{array}$ \\
\hline elect $_{\tau}$ & $\begin{array}{c}-5.242 \\
(0.129)\end{array}$ & $\begin{array}{l}-3.420 \\
(0.360)\end{array}$ & $\begin{array}{c}5.855 \\
(0.329)\end{array}$ & $\begin{array}{c}-6.644 \\
(0.119)\end{array}$ & $\begin{array}{c}-8.924 \\
(0.243)\end{array}$ & $\begin{array}{c}-11.573 \\
(0.290)\end{array}$ \\
\hline elect $_{\tau+1}$ & $\begin{array}{l}-5.195 \\
(0.116)\end{array}$ & $\begin{array}{c}-4.222 \\
(0.238)\end{array}$ & $\begin{array}{c}5.752 \\
(0.352)\end{array}$ & $\begin{array}{c}-9.228 \\
(0.034)\end{array}$ & $\begin{array}{c}2.812 \\
(0.718)\end{array}$ & $\begin{array}{c}9.526 \\
(0.397)\end{array}$ \\
\hline$D A T$ & $\begin{array}{c}5.801 \\
(0.044)\end{array}$ & $\begin{array}{c}2.991 \\
(0.326)\end{array}$ & $\begin{array}{c}4.347 \\
(0.367)\end{array}$ & $\begin{array}{c}-4.225 \\
(0.220)\end{array}$ & $\begin{array}{c}9.650 \\
(0.120)\end{array}$ & $\begin{array}{c}7.203 \\
(0.412)\end{array}$ \\
\hline D1985 & & & & $\begin{array}{l}-35.032 \\
(0.001)\end{array}$ & & \\
\hline D1990 & $\begin{array}{l}-25.656 \\
(0.001)\end{array}$ & $\begin{array}{c}-31.498 \\
(0.000)\end{array}$ & & $\begin{array}{c}-35.236 \\
(0.000)\end{array}$ & & \\
\hline$g_{k t-1}$ & $\begin{array}{c}-0.554 \\
(0.000)\end{array}$ & $\begin{array}{c}-0.337 \\
(0.029)\end{array}$ & & & & \\
\hline$g_{k t-2}$ & $\begin{array}{c}-0.474 \\
(0.001)\end{array}$ & $\begin{array}{l}-0.257 \\
(0.081)\end{array}$ & & & & \\
\hline$R^{2}$ & 0.689 & 0.611 & 0.290 & 0.625 & 0.160 & 0.252 \\
\hline
\end{tabular}

Figures in parenthesis are $p$-values. DAT denotes a dichotomous variable to capture differences attributed to changing the source of data from 1990 on, while $D X$ refers to a dichotomous variable that seeks to remove outliers present in year $X$. The model specification tests are available upon request.

Source: authors' elaboration based on data from IMF (various) and ECLAC (2015). 
Table 6.

Econometric estimation of PBuC in Colombia controlling by total government revenues, 1982-2014

\begin{tabular}{|c|c|c|c|c|c|c|}
\hline Expenditure & Total & $\begin{array}{c}\text { Current } \\
\text { expenditure }\end{array}$ & $\begin{array}{c}\text { Expenditure } \\
\text { on goods and } \\
\text { services }\end{array}$ & $\begin{array}{l}\text { Subsidies and } \\
\text { other current } \\
\text { transferences }\end{array}$ & $\begin{array}{c}\text { Capital } \\
\text { expenditure }\end{array}$ & $\begin{array}{l}\text { Acquisition of } \\
\text { fixed capital } \\
\text { assets }\end{array}$ \\
\hline Intercept & $\begin{array}{c}6.513 \\
(0.174)\end{array}$ & $\begin{array}{c}6.172 \\
(0.207)\end{array}$ & $\begin{array}{c}-14.652 \\
(0.018)\end{array}$ & $\begin{array}{c}10.687 \\
(0.085)\end{array}$ & $\begin{array}{l}-7.355 \\
(0.325)\end{array}$ & $\begin{array}{c}-15.457 \\
(0.145)\end{array}$ \\
\hline$i_{t}$ & $\begin{array}{c}0.206 \\
(0.401)\end{array}$ & $\begin{array}{c}0.271 \\
(0.304)\end{array}$ & $\begin{array}{c}1.068 \\
(0.005)\end{array}$ & $\begin{array}{c}0.332 \\
(0.314)\end{array}$ & $\begin{array}{c}0.724 \\
(0.075)\end{array}$ & $\begin{array}{c}1.157 \\
(0.048)\end{array}$ \\
\hline elect $_{\tau-1}$ & $\begin{array}{l}-2.240 \\
(0.612)\end{array}$ & $\begin{array}{c}-3.676 \\
(0.444)\end{array}$ & $\begin{array}{l}22.275 \\
(0.001)\end{array}$ & $\begin{array}{c}-2.206 \\
(0.713)\end{array}$ & $\begin{array}{c}3.580 \\
(0.624)\end{array}$ & $\begin{array}{l}23.163 \\
(0.031)\end{array}$ \\
\hline elect $_{\tau}$ & $\begin{array}{l}-6.335 \\
(0.196)\end{array}$ & $\begin{array}{l}-3.377 \\
(0.505)\end{array}$ & $\begin{array}{c}17.374 \\
(0.016)\end{array}$ & $\begin{array}{l}-7.606 \\
(0.234)\end{array}$ & $\begin{array}{l}-2.033 \\
(0.789)\end{array}$ & $\begin{array}{l}-2.890 \\
(0.791)\end{array}$ \\
\hline elect $_{\tau+1}$ & $\begin{array}{l}-3.284 \\
(0.453)\end{array}$ & $\begin{array}{l}-1.386 \\
(0.774)\end{array}$ & $\begin{array}{c}4.459 \\
(0.462)\end{array}$ & $\begin{array}{l}-7.768 \\
(0.204)\end{array}$ & $\begin{array}{c}8.392 \\
(0.267)\end{array}$ & $\begin{array}{c}12.237 \\
(0.245)\end{array}$ \\
\hline$D A T$ & $\begin{array}{c}5.568 \\
(0.144)\end{array}$ & $\begin{array}{l}-0.320 \\
(0.933)\end{array}$ & $\begin{array}{l}-0.426 \\
(0.931)\end{array}$ & $\begin{array}{l}-2.223 \\
(0.641)\end{array}$ & $\begin{array}{c}4.889 \\
(0.425)\end{array}$ & $\begin{array}{c}4.232 \\
(0.606)\end{array}$ \\
\hline$g_{k t-1}$ & $\begin{array}{l}-0.472 \\
(0.014)\end{array}$ & & $\begin{array}{l}-0.107 \\
(0.534)\end{array}$ & & $\begin{array}{c}0.329 \\
(0.069)\end{array}$ & \\
\hline$g_{k t-2}$ & $\begin{array}{l}-0.377 \\
(0.039)\end{array}$ & & $\begin{array}{c}0.242 \\
(0.236)\end{array}$ & & & \\
\hline$R^{2}$ & 0.404 & 0.094 & 0.499 & 0.152 & 0.329 & 0.352 \\
\hline
\end{tabular}

Figures in parenthesis are $p$-values. DAT denotes a dichotomous variable to capture differences attributed to changing the source of data from 1990 on, while $D X$ refers to a dichotomous variable that seeks to remove outliers present in year $X$. The model specification tests are available upon request.

Source: authors' elaboration based on data from IMF (various) and ECLAC (2015). 
Pablo Mejía Reyes • Marlen Rocio Reyes Hernández • Paolo Riguzzi

Table 7.

Econometric estimation of PBUC in Chile controlling by the GDP growth rate, 1982-2014

\begin{tabular}{|c|c|c|c|c|c|c|}
\hline Expenditure & Total* & $\begin{array}{c}\text { Current } \\
\text { expenditure }\end{array}$ & $\begin{array}{c}\text { Expenditure } \\
\text { on goods and } \\
\text { services }\end{array}$ & $\begin{array}{c}\text { Capital } \\
\text { expenditure }\end{array}$ & $\begin{array}{l}\text { Acquisition of } \\
\text { fixed capital } \\
\text { assets }\end{array}$ & $\begin{array}{c}\text { Capital } \\
\text { transferences }\end{array}$ \\
\hline Intercept & $\begin{array}{c}0.670 \\
(0.744)\end{array}$ & $\begin{array}{c}0.681 \\
(0.734)\end{array}$ & $\begin{array}{l}-4.923 \\
(0.044)\end{array}$ & $\begin{array}{c}0.242 \\
(0.956)\end{array}$ & $\begin{array}{l}-2.590 \\
(0.523)\end{array}$ & $\begin{array}{l}23.751 \\
(0.118)\end{array}$ \\
\hline$c$ & $\begin{array}{l}-0.036 \\
(0.874)\end{array}$ & $\begin{array}{c}0.096 \\
(0.698)\end{array}$ & $\begin{array}{c}0.466 \\
(0.084)\end{array}$ & $\begin{array}{c}1.235 \\
(0.015)\end{array}$ & $\begin{array}{c}1.272 \\
(0.008)\end{array}$ & $\begin{array}{l}-0.985 \\
(0.541)\end{array}$ \\
\hline elect $_{\tau-1}$ & $\begin{array}{c}3.784 \\
(0.194)\end{array}$ & $\begin{array}{c}4.551 \\
(0.093)\end{array}$ & $\begin{array}{c}2.194 \\
(0.507)\end{array}$ & $\begin{array}{c}2.895 \\
(0.633)\end{array}$ & $\begin{array}{l}-2.157 \\
(0.703)\end{array}$ & $\begin{array}{l}21.718 \\
(0.284)\end{array}$ \\
\hline elect $_{\tau}$ & $\begin{array}{c}-1.581 \\
(0.578)\end{array}$ & $\begin{array}{c}2.360 \\
(0.434)\end{array}$ & $\begin{array}{c}0.983 \\
(0.763)\end{array}$ & $\begin{array}{c}2.992 \\
(0.618)\end{array}$ & $\begin{array}{c}2.178 \\
(0.697)\end{array}$ & $\begin{array}{c}-14.724 \\
(0.460)\end{array}$ \\
\hline elect $_{\tau+1}$ & $\begin{array}{l}-5.648 \\
(0.064)\end{array}$ & $\begin{array}{l}-2.287 \\
(0.409)\end{array}$ & $\begin{array}{l}-2.807 \\
(0.412)\end{array}$ & $\begin{array}{c}-13.146 \\
(0.042)\end{array}$ & $\begin{array}{r}-13.897 \\
(0.023)\end{array}$ & $\begin{array}{l}-7.451 \\
(0.719)\end{array}$ \\
\hline$D A T$ & $\begin{array}{c}5.665 \\
(0.024)\end{array}$ & $\begin{array}{c}2.724 \\
(0.302)\end{array}$ & $\begin{array}{c}7.505 \\
(0.010)\end{array}$ & $\begin{array}{c}1.481 \\
(0.770)\end{array}$ & $\begin{array}{c}4.137 \\
(0.385)\end{array}$ & $\begin{array}{l}-3.435 \\
(0.842)\end{array}$ \\
\hline D1984 & & & & & & $\begin{array}{c}183.673 \\
(0.000)\end{array}$ \\
\hline D1989 & & $\begin{array}{r}-23.254 \\
(0.002)\end{array}$ & & & & \\
\hline$g_{k t-1}$ & & $\begin{array}{c}0.104 \\
(0.511)\end{array}$ & & & & \\
\hline$R^{2}$ & 0.301 & 0.519 & 0.354 & 0.342 & 0.362 & 0.460 \\
\hline
\end{tabular}

Figures in parenthesis are p-values. DAT denotes a dichotomous variable to capture differences attributed to changing the source of data from 1990 on, while DX refers to a dichotomous variable that seeks to remove outliers present in year $\mathrm{X}$. The model specification tests are available upon request. * Heteroskedasticity consistent standard errors (White correction). Source: authors' elaboration based on data from IMF (various) and ECLAC (2015). 
Table 8.

Econometric estimation of PBuC in Chile controlling by the GDP gap, 1982-2014

\begin{tabular}{|c|c|c|c|c|c|c|}
\hline Expenditure & Total* & $\begin{array}{c}\text { Current } \\
\text { expenditure }\end{array}$ & $\begin{array}{l}\text { Expenditure } \\
\text { on goods and } \\
\text { services }\end{array}$ & $\begin{array}{c}\text { Capital } \\
\text { expenditure }\end{array}$ & $\begin{array}{l}\text { Acquisition of } \\
\text { fixed capital } \\
\text { assets }\end{array}$ & $\begin{array}{c}\text { Capital } \\
\text { transferences }\end{array}$ \\
\hline Intercept & $\begin{array}{c}2.758 \\
(0.085)\end{array}$ & $\begin{array}{c}2.806 \\
(0.060)\end{array}$ & $\begin{array}{c}-2.793 \\
(0.216)\end{array}$ & $\begin{array}{c}4.351 \\
(0.331)\end{array}$ & $\begin{array}{c}1.974 \\
(0.642)\end{array}$ & $\begin{array}{l}19.421 \\
(0.166)\end{array}$ \\
\hline$c$ & $\begin{array}{l}56.610 \\
(0.001)\end{array}$ & $\begin{array}{r}64.826 \\
(0.001)\end{array}$ & $\begin{array}{l}37.251 \\
(0.163)\end{array}$ & $\begin{array}{l}-22.971 \\
(0.661)\end{array}$ & $\begin{array}{c}2.746 \\
(0.956)\end{array}$ & $\begin{array}{c}-162.885 \\
(0.306)\end{array}$ \\
\hline elect $_{\tau-1}$ & $\begin{array}{c}4.275 \\
(0.091)\end{array}$ & $\begin{array}{c}4.280 \\
(0.047)\end{array}$ & $\begin{array}{c}2.855 \\
(0.393)\end{array}$ & $\begin{array}{c}5.302 \\
(0.425)\end{array}$ & $\begin{array}{c}0.179 \\
(0.977)\end{array}$ & $\begin{array}{l}20.414 \\
(0.302)\end{array}$ \\
\hline elect $_{\tau}$ & $\begin{array}{c}2.857 \\
(0.259)\end{array}$ & $\begin{array}{c}3.266 \\
(0.167)\end{array}$ & $\begin{array}{c}0.966 \\
(0.771)\end{array}$ & $\begin{array}{c}2.501 \\
(0.706)\end{array}$ & $\begin{array}{c}1.769 \\
(0.780)\end{array}$ & $\begin{array}{r}-15.362 \\
(0.436)\end{array}$ \\
\hline elect $_{\tau+1}$ & $\begin{array}{l}-3.571 \\
(0.019)\end{array}$ & $\begin{array}{c}-1.534 \\
(0.488)\end{array}$ & $\begin{array}{c}-2.474 \\
(0.479)\end{array}$ & $\begin{array}{l}-13.830 \\
(0.054)\end{array}$ & $\begin{array}{l}-14.261 \\
(0.038)\end{array}$ & $\begin{array}{l}-9.430 \\
(0.647)\end{array}$ \\
\hline$D A T$ & $\begin{array}{c}1.624 \\
(0.336)\end{array}$ & $\begin{array}{c}0.911 \\
(0.635)\end{array}$ & $\begin{array}{c}7.402 \\
(0.013)\end{array}$ & $\begin{array}{c}3.674 \\
(0.516)\end{array}$ & $\begin{array}{c}5.860 \\
(0.282)\end{array}$ & $\begin{array}{l}-2.543 \\
(0.881)\end{array}$ \\
\hline D1984 & & & & & & $\begin{array}{l}172.130 \\
(0.000)\end{array}$ \\
\hline D1989 & $\begin{array}{l}-20.127 \\
(0.000)\end{array}$ & $\begin{array}{l}-24.802 \\
(0.000)\end{array}$ & & & & \\
\hline $\mathrm{R}^{2}$ & 0.629 & 0.672 & 0.330 & 0.196 & 0.184 & 0.473 \\
\hline
\end{tabular}

Figures in parenthesis are p-values. DAT denotes a dichotomous variable to capture differences attributed to changing the source of data from 1990 on, while DX refers to a dichotomous variable that seeks to remove outliers present in year X. The model specification tests are available upon request.

Source: authors' elaboration based on data from IMF (various) and ECLAC (2015). 
Pablo Mejía Reyes • Marlen Rocio Reyes Hernández • Paolo Riguzzi

Table 9.

Econometric estimation of $\mathrm{PBuC}$ in Chile controlling by total government revenues, 1982-2014

\begin{tabular}{|c|c|c|c|c|c|c|}
\hline Expenditure & Total & $\begin{array}{c}\text { Current } \\
\text { expenditure }\end{array}$ & $\begin{array}{c}\text { Expenditure } \\
\text { on goods and } \\
\text { services }\end{array}$ & $\begin{array}{c}\text { Capital } \\
\text { expenditure }\end{array}$ & $\begin{array}{l}\text { Acquisition of } \\
\text { fixed capital } \\
\text { assets }\end{array}$ & $\begin{array}{c}\text { Capital } \\
\text { transferences }\end{array}$ \\
\hline Intercept & $\begin{array}{c}0.750 \\
(0.689)\end{array}$ & $\begin{array}{c}0.942 \\
(0.620)\end{array}$ & $\begin{array}{c}-3.782 \\
(0.087)\end{array}$ & $\begin{array}{c}3.682 \\
(0.383)\end{array}$ & $\begin{array}{c}1.341 \\
(0.746)\end{array}$ & $\begin{array}{l}20.724 \\
(0.145)\end{array}$ \\
\hline$i_{t}$ & $\begin{array}{l}-0.098 \\
(0.369)\end{array}$ & $\begin{array}{l}-0.067 \\
(0.553)\end{array}$ & $\begin{array}{c}0.245 \\
(0.058)\end{array}$ & $\begin{array}{c}0.451 \\
(0.072)\end{array}$ & $\begin{array}{c}0.281 \\
(0.246)\end{array}$ & $\begin{array}{c}-0.391 \\
(0.627)\end{array}$ \\
\hline elect $_{\tau-1}$ & $\begin{array}{l}3.867 \\
(0.175)\end{array}$ & $\begin{array}{c}4.774 \\
(0.075)\end{array}$ & $\begin{array}{c}2.684 \\
(0.408)\end{array}$ & $\begin{array}{c}4.492 \\
(0.476)\end{array}$ & $\begin{array}{c}-0.234 \\
(0.970)\end{array}$ & $\begin{array}{l}20.596 \\
(0.306)\end{array}$ \\
\hline elect $_{\tau}$ & $\begin{array}{l}-1.915 \\
(0.500)\end{array}$ & $\begin{array}{c}1.881 \\
(0.537)\end{array}$ & $\begin{array}{c}1.687 \\
(0.605)\end{array}$ & $\begin{array}{c}4.166 \\
(0.512)\end{array}$ & $\begin{array}{c}2.746 \\
(0.660)\end{array}$ & $\begin{array}{l}-15.667 \\
(0.436)\end{array}$ \\
\hline elect $_{\tau+1}$ & $\begin{array}{l}-5.467 \\
(0.070)\end{array}$ & $\begin{array}{l}-2.378 \\
(0.386)\end{array}$ & $\begin{array}{l}-3.377 \\
(0.321)\end{array}$ & $\begin{array}{r}-14.313 \\
(0.036)\end{array}$ & $\begin{array}{c}-14.783 \\
(0.028)\end{array}$ & $\begin{array}{c}-6.411 \\
(0.758)\end{array}$ \\
\hline$D A T$ & $\begin{array}{c}5.852 \\
(0.018)\end{array}$ & $\begin{array}{c}3.564 \\
(0.167)\end{array}$ & $\begin{array}{c}7.567 \\
(0.009)\end{array}$ & $\begin{array}{c}2.120 \\
(0.689)\end{array}$ & $\begin{array}{c}5.237 \\
(0.319)\end{array}$ & $\begin{array}{c}-3.574 \\
(0.837)\end{array}$ \\
\hline D1984 & & & & & & $\begin{array}{c}186.964 \\
(0.000)\end{array}$ \\
\hline D1989 & & $\begin{array}{r}-20.682 \\
(0.004)\end{array}$ & & & & \\
\hline$g_{k t-1}$ & & $\begin{array}{l}-0.051 \\
(0.738)\end{array}$ & & & & \\
\hline$R^{2}$ & 0.320 & 0.523 & 0.368 & 0.278 & 0.222 & 0.457 \\
\hline
\end{tabular}

Figures in parenthesis are $p$-values. DAT denotes a dichotomous variable to capture differences attributed to changing the source of data from 1990 on, while $D X$ refers to a dichotomous variable that seeks to remove outliers present in year $X$. The model specification tests are available upon request.

Source: authors' elaboration based on data from IMF (various) and ECLAC (2015). 


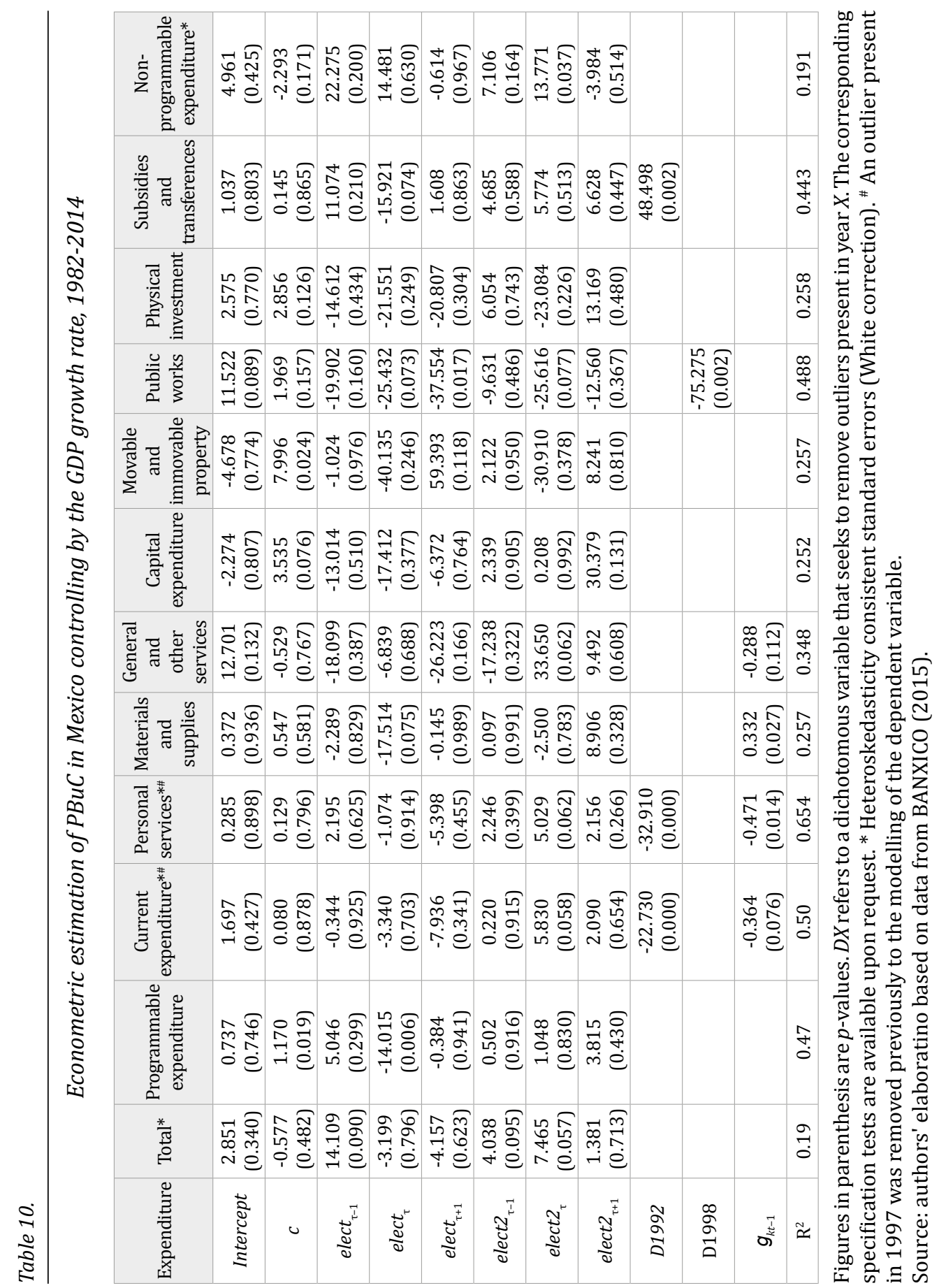


Pablo Mejía Reyes • Marlen Rocio Reyes Hernández • Paolo Riguzzi

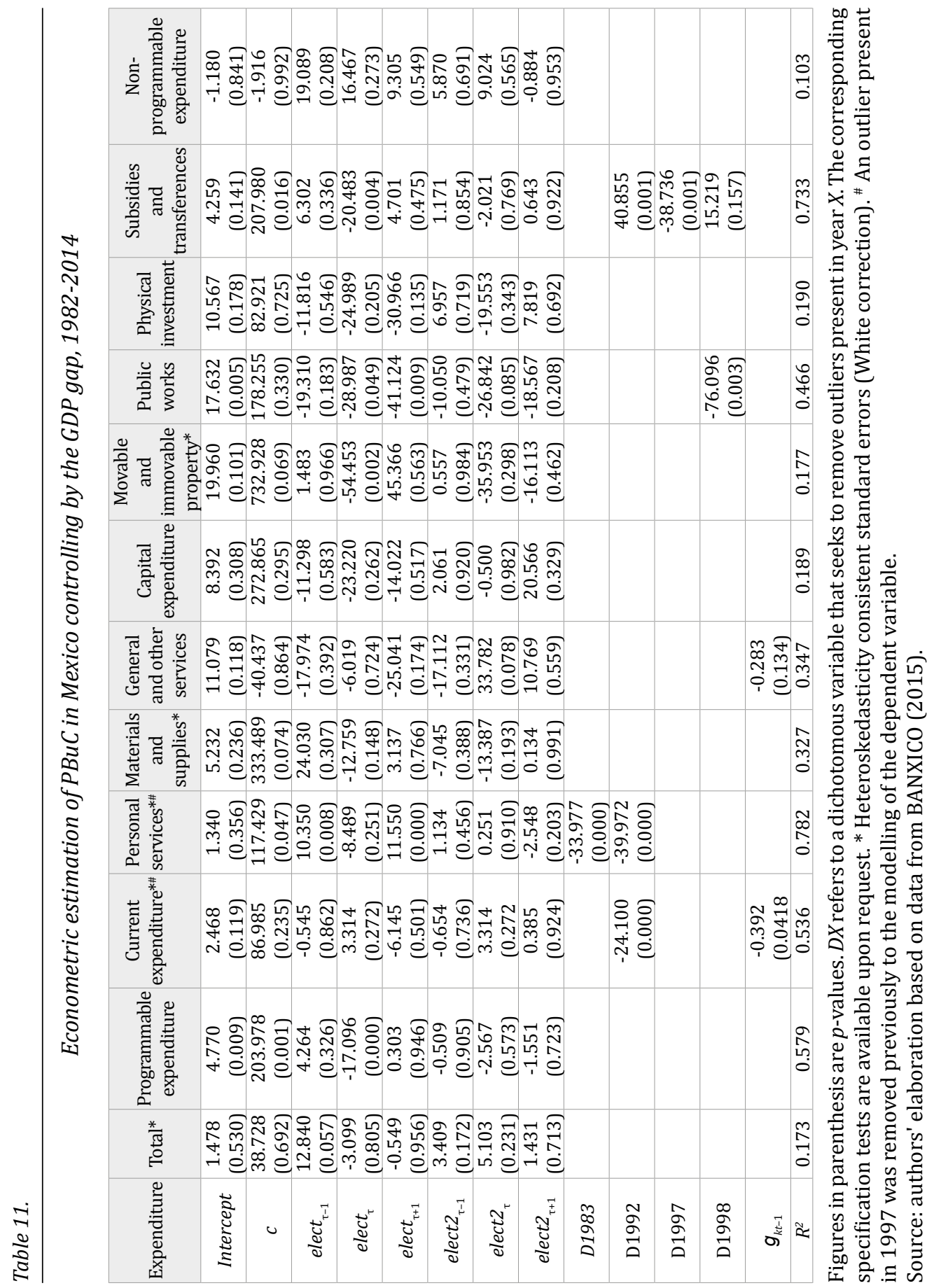




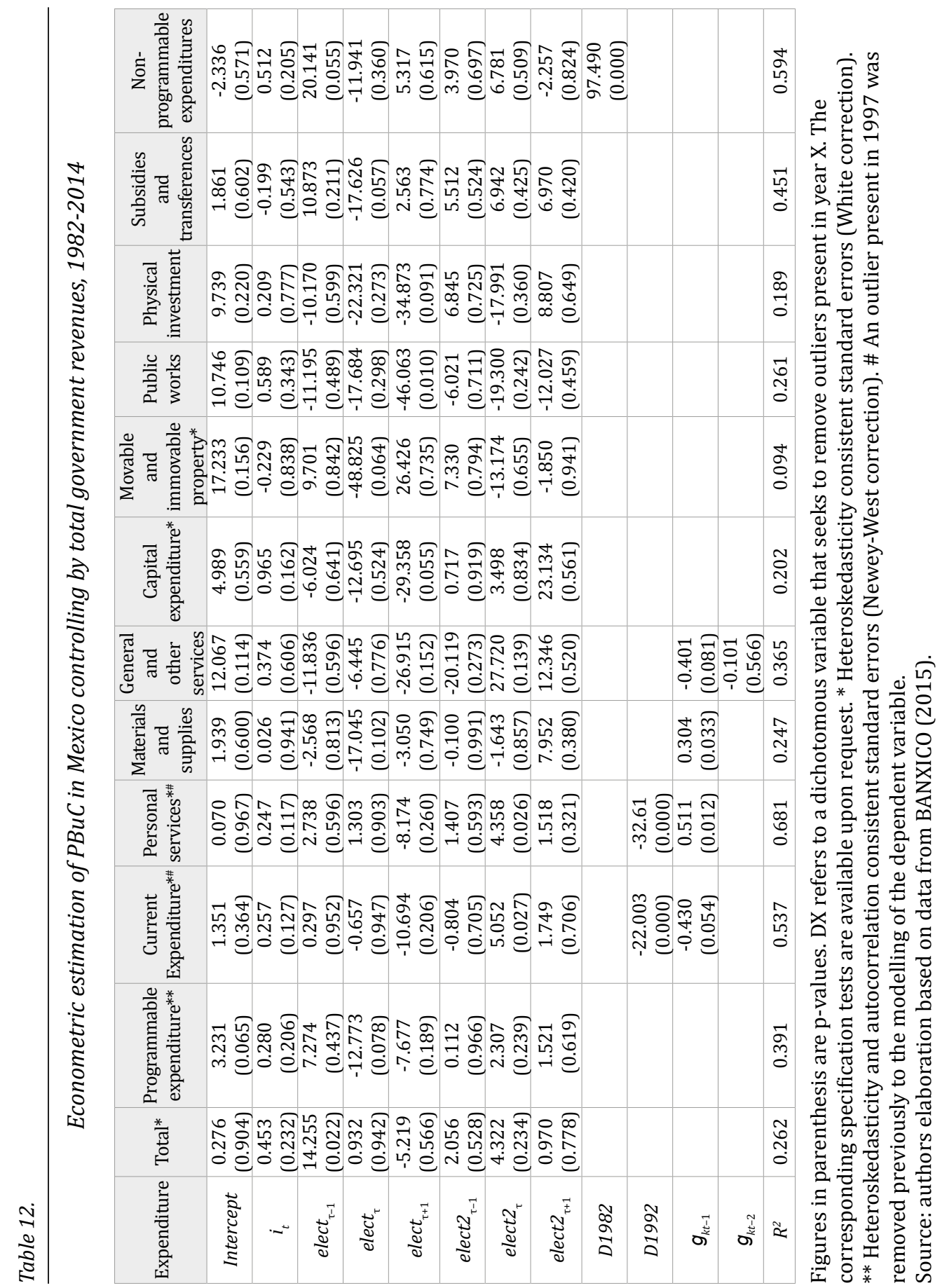

